\title{
Article
}

\section{Picophytoplankton in freshwater ecosystems: the importance of small-sized phototrophs}

\author{
Cristiana Callieri \\ CNR-ISE Institute of Ecosystem Study, Largo Tonolli 50, 28922 Verbania, Italy. Email: c.callieri@ise.cnr.it
}

Received 20 April 2007; accepted 19 May 2007; published 20 December 2007

\section{Abstract}

About 40 years have passed since the discovery of picophytoplankton; the present knowledge of the taxonomy, physiology and ecology of these tiny photoautotrophic cells offers new perspectives on the importance of the microbial contribution to global biogeochemical cycles and food webs. This review focuses on the relationships among the components of picophytoplankton (picocyanobacteria and the picoplanktic eukaryotes) and biotic and abiotic environmental factors. The dynamics of picophytoplankton in aquatic ecosystems are strictly dependent upon basin size and trophy, temperature, and nutrient and light limitation, but they are also regulated by grazing and viral-induced lysis. The review considers: the pros and cons of the molecular approach to the study of the taxonomy of freshwater Synechococcus spp.; the importance of ecological aspects in understanding the puzzle of picophytoplankton phylogeny (genotype vs ecotype); and the role of biotic vs abiotic interactions in controlling picophytoplankton dynamics. Biotic, topdown control mechanisms are reviewed as well as knowledge of other biological interactions.

Keywords: Picocyanobacteria; picoeukaryotes; freshwater autotrophic picoplankton; Synechococcus; historical perspectives; taxonomy; phylogenetic diversity; ecology; population dynamics.

\section{A brief introduction}

The picophytoplankton comprises small (size range: $0.2 \mu \mathrm{m}$ to $2 \mu \mathrm{m})$ prokaryotic picocyanobacteria and eukaryotic phototrophs. They are distributed worldwide and are ubiquitous in all types of lakes and ocean, of varying trophic state (Stockner \& Antia, 1986). Formally, the term 'picophytoplankton' should be restricted to solitary living unicells; however, in fresh waters, microcolonies of 'non-blooming' species comprising a few to $>50$ individual cells are included in the picophytoplankton (Stockner et al., 2000).
The picophytoplankton is of great importance in the carbon flow of oceans and of many lakes: in ultraoligotrophic waters, some $50 \%$ to $70 \%$ of the carbon fixed annually is attributed to organisms that pass through filters with pore sizes of $1 \mu \mathrm{m}$ to $2 \mu \mathrm{m}$ (Caron et al., 1985). The understanding of the taxonomy, dynamics and ecology of these organisms are continuously enriched thanks to developments in molecular biology and to the introduction of increasingly sophisticated equipment directed at the analysis of the properties of single cells. The challenge now is to understand better the relationship between the diversity and physiology 
of the various ecotypes, how these interact with each other and with the environmental factors that allow the proliferation of the most competitive genotypes.

\section{Historical perspective}

The earliest subdivision of the phytoplankton into size categories owes to Schütt (1892). During the 1950s, following the introduction of a variety of screens, nets and filters of differing pore sizes to separate the fractions of plankton, terms to distinguish micro-, nano- and ultraplankton were introduced (Table 1). The presence of coccoid blue-green algae (Cyanobacteria), bacteria and yeasts among the biota of open water had been recognised by Lohmann (1911), who called all these small organisms 'nanoplankton'; although he was unable to quantify their biomass, he surmised their importance to the economy of natural waters. We had to wait another four decades before Verduin (1956) showed experimentally that a large part of photosynthetic activity in lakes was contributed by organisms that passed through a $64 \mu \mathrm{m}$ mesh plankton net. Then, in a study of size fractionation of ${ }^{14} \mathrm{C}$-labelled plankton in the sea, Holmes \& Anderson (1963) indicated 'the possible existence of minute autotrophic organisms $(<1 \mu \mathrm{m})^{\prime}$. However, the first study to confirm the widespread abundance of Synechococcus as one of the most important components of freshwater picophytoplankton was carried out in Loch Leven (Scotland), by BaileyWatts et al. (1968). Their description, published in the prestigious journal Nature, included information on the temporal dynamics of the biomass and its photosynthetic production but could only ascribe the organism to an 'undescribed species of the genus Synechococcus'.

The term, picoplankton, was introduced in the size classification of plankton published by Sieburth et al. (1978) and is, essentially, that which continues in widespread use today; interestingly, this referred only to the 'heterotrophic picoplankton', or bacterioplankton. It was following years of further research on mainly oceanic picoplankton that the widespread and significant contribution of unicellular chroococcoid Cyanobacteria to the marine picoplankton began to be recognised in the literature (Johnson \& Sieburth, 1979; Waterbury et al., 1979; Li et al., 1983). Furthermore, it was clearly recognised that the picophytoplankton included not only prokaryotic cells but also eukaryotic microalgae (Johnson \& Sieburth, 1982).

Major advances in picophytoplankton ecology, physiology and taxonomy were made in the 1970s and 1980s, thanks to the introduction of new techniques of epifluorescence microscopy (Daley \& Hobbie, 1975), flow cytometry (Olson et al., 1985; Chisholm et al., 1988) and electron microscopy (Johnson \& Sieburth, 1982; Takahashi \& Hori, 1984). In 1986, several comprehensive reviews (Fogg, 1986; Platt \& Li, 1986; Stockner \& Antia,

Table 1. Classification of plankton of microscopic and submicroscopic size (from Sicko-Goad \& Stoermer, 1984; modified).

\begin{tabular}{lll}
\hline Terminology & Size $(\mu \mathrm{m})$ & References \\
\hline Net plankton & $>64$ & Vollenweider et al., 1974 \\
Microplankton & $20-200$ & Dussart, 1965; Sieburth et al., 1978 \\
& $50-500$ & Margalef, 1955 \\
Nanoplankton & $60-500$ & Hutchinson, 1967 \\
& $2-20$ & Dussart, 1965; Sieburth et al., 1978 \\
& $5-50$ & Margalef, 1955 \\
& $5-60$ & Hutchinson, 1967 \\
Ultraplankton & $<64$ & Vollenweider et al., 1974 \\
& $<5$ & Margalef, 1955 \\
Picoplankton & $0.5-5$ & Hutchinson, 1967 \\
Femtoplankton & $0.2-2$ & Sieburth et al.,1978 \\
\hline
\end{tabular}


1986) were able to discuss the taxonomy, biochemistry, physiological ecology of picophytoplankton and their dynamics in pelagic ecosystems for the first time.

The introduction of molecular biology to microbial ecology has revolutionised our knowledge of aquatic ecosystems. For the first time, it was possible to determine the composition of the picoplanktonic compartment without having either to observe it under the microscope or to cultivate it. The sequence of a gene present in all living organisms, that coding the small sub-units (SSU) of ribosomal RNA (rRNA), was determined. The analysis of specific sequences allows the source organism to be placed in the phylogenetic tree. Furthermore, it has been possible to ascertain from small sequences within this gene the characteristics of a group of organisms and to synthesise molecular 'probes' that recognise and identify this region of the DNA of test organisms. The phylogenetic analysis of 16S rRNA (for picocyanobacteria) and $18 \mathrm{~S}$ rRNA (for picoeukaryotes) gene sequences has proved a powerful tool in the assessment of phylogenetic relationships among strains with homologous sequences.

\section{Taxonomy}

Morphological features of picophytoplankton are insufficiently distinct to provide any basis for taxonomic discrimination. Initially, classification relied mainly on the diagnosis of physiological properties, expressed in pure culture (Rippka, 1988). Ultrastructural studies, ecological analysis and, in particular, molecular methods have substantially improved the criteria for classification. The definition of prokaryotic species is difficult (Staley, 1997; Komárek et al., 2004); nowadays, biodiversity studies at the microbial size focus on clade and/or strain divergence in the phylogenetic tree rather than on morphological differences. The true taxonomic position of a microorganism may even be mis-placed as a result of morphological plasticity. For this reason, it is important always to consider the phenotypic diversity in conjunction with genotypic analysis in order to resolve whether phenotypic similarity reflects close phylogenetic relationship or is the result of convergent evolution.
Nevertheless, the genetic diversity of microbes is strictly dependent upon the primers chosen and the analyses performed; thus, the molecular data do not provide unequivocal phylogenetic information (Wilmotte \& Golubić, 1991). The combination of molecular and ecophysiological approaches offers the most favourable approach to understanding picophytoplankton diversity. Amplifying investigations commonly begin with an observation of cells using epifluorescence microscopy to make a first separation based on pigment autofluorescence (Fig. 1 and Fig. 2). Under blue-wavelength excitation (BP450 to BP490, FT510, LP520), picoeukaryotes appear red, due to chlorophyll- $a$ fluorescence, whereas picocyanobacteria fluoresce yellow (PE-cells: phycoerythrin cells) or dark red (PC-cells: phycocyanin cells), depending on the presence or absence of the phycobiliprotein, phycoerythrin. The spectral signature of PE-cells is one aspect of the organismic phenotype, referred to as its spectral phenotype (McMurter \& Pick, 1994). Whereas PE-containing Synechococcus spp. show an emission maximum at $578 \mathrm{~nm}$ when excited at $520 \mathrm{~nm}$, PC phenotypes emit maximally at $648 \mathrm{~nm}$ when excited at $600 \mathrm{~nm}$ (Ernst, 1991; Callieri et al., 1996).

A powerful technique for counting cells of differing sizes and fluorescence spectra is offered by flow cytometry (Diamond \& DeMaggio, 2000). The use of this instrument certainly improves the accuracy of counts as more measurements can be made than by direct microscopic countings; to date, it is the best means of counting picophytoplankton cells and of simultaneously

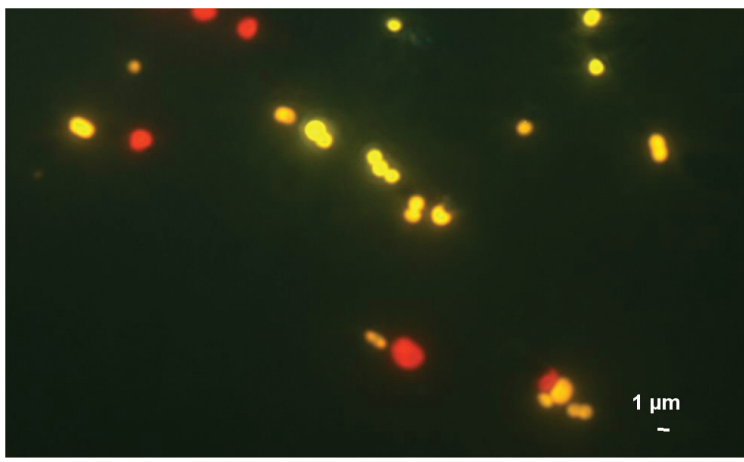

Fig. 1. Picophytoplankton cells from Lake Maggiore (Northern Italy) under epifluorescence microscopy (blue excitation). PE-cell picocyanobacteria appear yellow and picoeukaryotes appear red. 
distinguishing single cells and single colonies of varying size and pigmentation (Crosbie et al., 2003a). Using flow-cytometry, Crosbie et al. (2003b) have made the first seasonal and vertical maps of the picophytoplankton of a mesotrophic lake. This study also successfully confronted the problem of distinguishing the distributions of single, picocyanobacterial cells from those of larger, colonial coccoid species of Cyanobacteria (Aphanothece spp., Microcystis spp.). Single cells typically characterise oligotrophic systems, whereas colonial bloom-formers are common in eutrophic systems. The study of microcolonies (e.g. formation conditions, taxonomy, ecotyping) could clarify many obscure points about the success of individual picocyanobacterial forms in a wide range of trophic conditions. One possible mechanism of microcolony formation is the excretion of photosynthaterich mucilage, which greatly facilitates clump development (Kiørboe \& Hansen, 1993). Nevertheless, the presence of microcolonies has been observed under the nutrientlimited conditions typical of lakes in late summer (Passoni \& Callieri, 2001; Komárková, 2002; Crosbie et al., 2003b); thus, the supposition that colony formation is a strategy for more efficient nutrient recycling appears unlikely (Ploug et al., 1999), because the external mucilage strongly limits the diffusive uptake of the cells inside the microcolony (Crosbie et al., 2003b). Indeed, the phosynthate-rich mucilage results from active photosynthesis during periods of severe nutrient deficits, in surface and nearsurface water (Crosbie et al., 2003b). The differing ecological roles of single cells and colonial forms (grazing

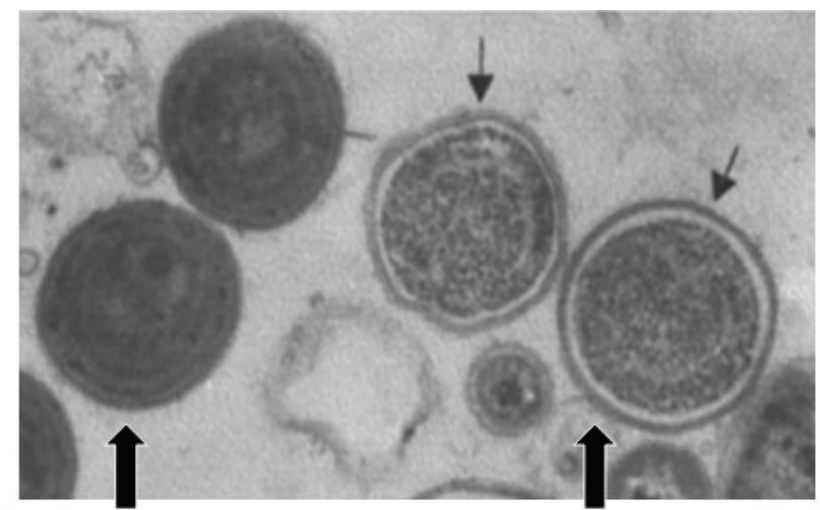

PC phycocyanin

PE phycoerythrin
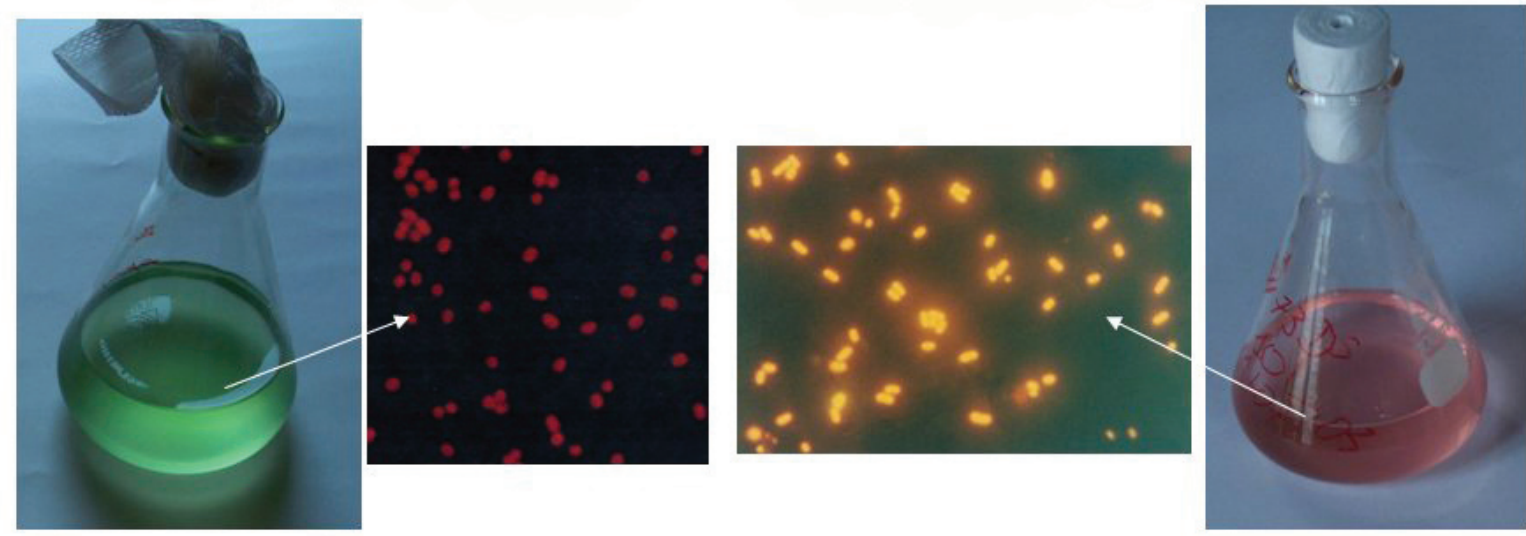

Fig. 2. Synechococcus sp. cultures with predominantly phycocyanin phycobiliprotein, lacking phycoerythrin (on the left) and with predominantly phycoerythrin phycobiliprotein (on the right). The microscopic fields are obtained with blue excitation at $1250 \times$ (Zeiss AXIOPLAN epifluorescence microscope). The upper part of the figure shows the internal structure of the two kinds of cells under transmission electron microscopy. 
pressure, sedimentation, depth colonisation, species interactions) stimulate many hypothetical scenarios for the frequency and dynamics of colony formation, both in the short- and the long-term. One of these, based on the close correlation between solitary picocyanobacteria and microcolonies, suggests that microcolonies are derived from single cells (Passoni \& Callieri, 2001). Microcolony formation from single cells of the phycocyanin-rich freshwater Cyanobium sp., induced by the grazing activities of the nanoflagellate, Ochromonas sp. DS, was recently demonstrated in laboratory experiments (Jezberová \& Komárková, 2007). The authors observed the formation of $1 \mu \mathrm{m}$ long tubes (spinae) on the cell surface. At present, it is not clear if the tube formation has any role in the aggregation, or whether it is species-specific. However, the behaviour is interpreted as an adaptive strategic defence against predation. Other experimental studies are necessary to amplify our understanding of the circumstances and dynamics of microcolony formation.

With the traditional methods used in the past, it was possible to describe the time-space dynamics of picophytoplankton in many aquatic ecosystems, from shallow eutrophic water bodies to large, deep, ultraoligotrophic lakes and oceans (see the references in Weisse, 1993; Stockner et al., 2000). This approach has led to an understanding about the presence of picophytoplankton in aquatic systems of differing trophic states and to the first ecological characterisation of the main component of picophytoplankton, the picocyanobacteria. Comparatively few studies have been directed towards the picoeukaryotes, whose identification in natural communities is recognised to be difficult, principally as a consequence of their small sizes and similar morphologies. Eukaryotic cells are generally larger than prokaryotic ones, owing to their more complex internal structure. As a result, the cells of many eukaryotic algae are generally around $5 \mu \mathrm{m}$ to $6 \mu \mathrm{m}$ or larger, thus placing them formally within the category of nanophytoplankton. Some of these can be discriminated at the Class level, using electron microscopy or high-pressure liquid chromatographic (HPLC) pigment analyses but most of them cannot readily be identified to lower taxonomic levels. Also, only a small percentage of the picoeukaryote species have been grown in culture, and there is no guarantee that those organisms currently available in pure culture are necessarily the same ones that dominate natural communities.

Approximation using molecular techniques offers a promising alternative to identification and establishing phyletic affinities, both for eukaryotic and prokaryotic picophytoplankton. The analysis of rDNA sequences uses techniques such as cloning and sequencing, and/or fingerprinting techniques, such as Denaturing Gradient Gel Electrophoresis (DGGE: based on the electrophoretic separation of partial SSU rDNA fragments of the same length but different base pair composition, within a linearly increasing gradient of denaturants; Muyzer et al., 1993) and Terminal Restriction Fragment Length Polymorphism (T-RFLP: measure of size polymorphism of the terminal restriction fragments from a PCRamplified marking performed with a fluorescently tagged primer; see Avaniss-Aghajani et al., 1994). These cultivation-independent molecular fingerprinting techniques have gained in popularity, as they permit us to address questions related to the diversity, structural composition and dynamics of picophytoplankton.

The introduction of such techniques, in conjunction with the use of flow cytometry, is expanding our ability to explore natural assemblages of picophytoplankton. This multi-faceted approach led to the discovery of the oceanic abundance of a primitive, prokaryotic picocyanobacterium of the Prochlorophyta group (Chisholm et al., 1988), having divinyl chlorophyll $a$ (chl- $\left.a_{2}\right)$ as its principal lightharvesting pigment, and divinyl chlorophyll $b$ (chl- $\left.b_{2}\right)$, zeaxanthin, alfa-carotene and a chlorophyll-c-like pigment as its main accessory pigments (Goericke \& Repeta, 1993). The small coccoid prochlorophyte, Prochlorococcus marinus, is abundant in the North Atlantic (Veldhuis \& Kraay, 1990), the tropical and subtropical Pacific (Campbell et al., 1994), the Mediterranean (Vaulot et al., 1990) and the Red Sea (Veldhuis \& Kraay, 1993). Among fresh waters, only a single filamentous form of prochlorophyte (Prochlorothrix) has been described, this coming from a eutrophic lake (Burger-Wiersma et al., 1986; Burger-Wiersma, 1991). Other published encounters of prochlorophytes in 


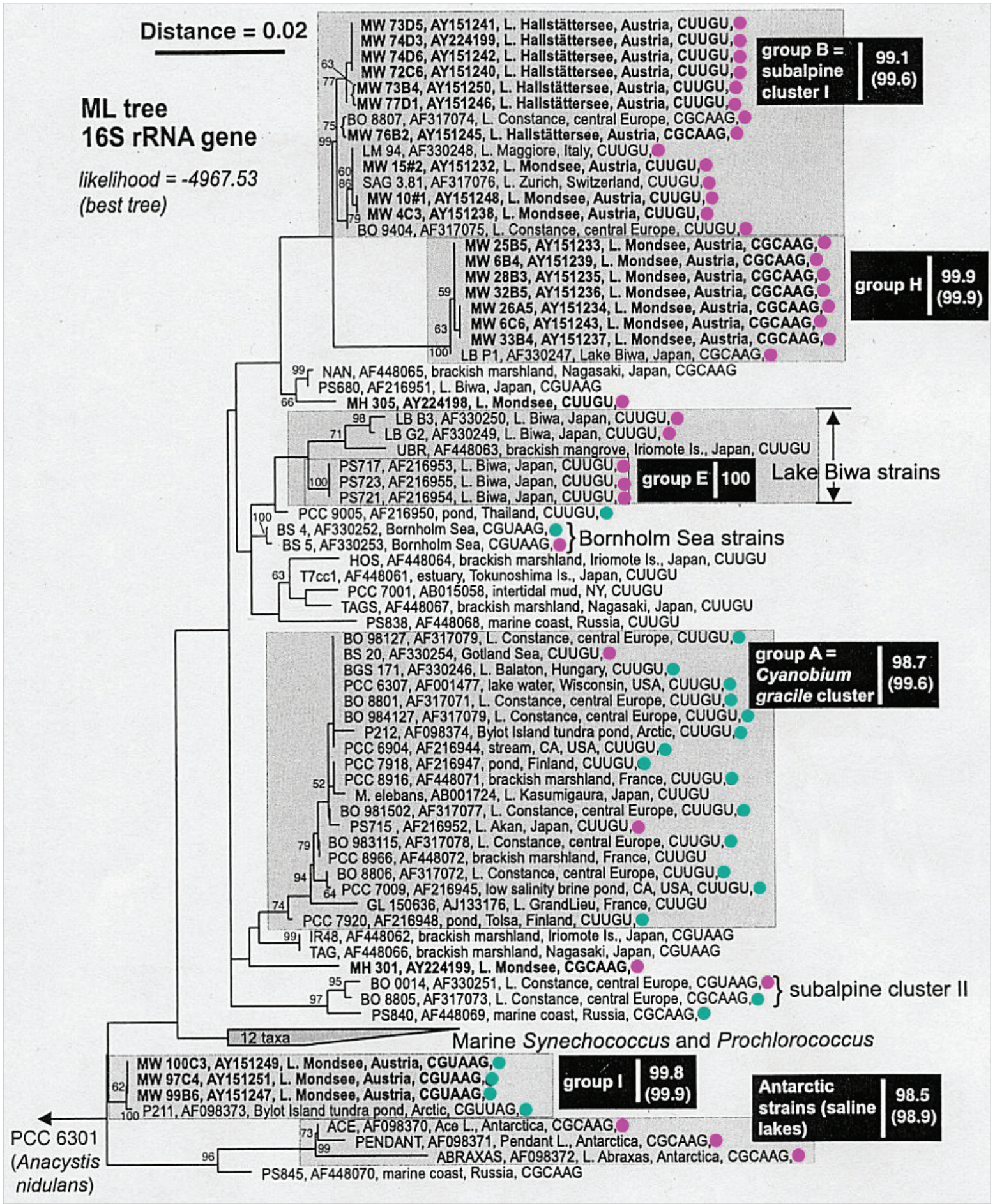

Fig. 3. Maximum-likelihood tree of the picophytoplankton clade sensu Urbach et al. inferred from $16 \mathrm{~S}$ rRNA gene sequences. Reproduced from Crosbie et al. (2003c) with the kind permission of the American Society for Microbiology. The green and pink dots indicate phycocyanin and phycoerythrin strains, respectively. 
fresh waters (Stockner \& Antia, 1986; Fahnenstiel et al., 1991a) may have been either PC-rich Cyanobacteria or Chlorella-like eukaryotic cells. Recently, Prochlorococcuslike cells have been discovered by flow cytometry in a eutrophic reservoir in Spain (Corzo et al., 1999) but this observation awaits the verification of alternative methods.

\section{Phylogenetic diversity of prokaryotic picophytoplankton}

At present, the phylogenetic analysis of the $16 \mathrm{~S}$ rDNA sequences indicates that members of the unicellular cyanobacterial Order Chroococcales are polyphyletic and dispersed among the Cyanobacteria (Urbach et al., 1998). It is now clear that two genera, Synechococcus and Cyanobium, dominate the prokaryotic picophytoplankton of fresh waters. Phylogenetic trees, based on the analysis of gene sequences revealed using $16 \mathrm{~S}$ rDNA, ITS-1 (Transcribed Spacer) and cpcBA-IGS (Intergenic Spacer between phycocyanin operon B, A and flanking regions) have been constructed (Robertson et al., 2001; Ernst et al., 2003; Crosbie et al., 2003c). The phylogenetic inferences of these trees rely on a limited number of isolated strains. The debate as to whether there is a widespread dispersal of some closely related clusters (Crosbie et al., 2003c) or there is an ecosystem-dependent radiation (Ernst et al., 2003) owes to the scarcity of acquired sequences and to the difficulty in gaining isolates considered to be representative of the place of their origin. This means that an isolate does not necessarily contain the most recent common ancestor of all its members and is, therefore, an unnatural taxon. Despite this uncertainty, the following statements apply to the phylogenetic evolution of Synechococcus:

- at least six to seven clusters of non-marine picocyanobacteria have been found within the picophytoplanktic clade, sensu Urbach et al. (1998) (Crosbie et al., 2003c, see Fig. 3);

- the PE-spectral phenotype does not appear to be a general character that can be used to define a clade (Everroad \& Wood, 2006);
- the Synechococcus-like morphology may represent an ancestral morphology type from which other morphology have evolved (Robertson et al., 2001).

We are only at the beginning of understanding the evolution and taxonomy of the picocyanobacteria. This perception is immediately apparent when looking over the phylogeny of the genera Synechococcus and Cyanobium. Within cyanobacterial radiation, for example, members of subcluster 5.2 (Crosbie et al., 2003c) of marine Synechococcus do not possess PE and are halotolerant; they are a sister-group to the form-genus Cyanobium of the Subalpine Subcluster II (Everroad \& Wood, 2006). In this sense the inclusion of multiple genetic markers and of strains from different aquatic systems (both marine and freshwater) could change the differentiation among clades, giving another perspective on the evolution of taxa.

\section{Phylogenetic diversity of eukaryotic picophytoplankton}

The eukaryotic component of picophytoplankton in fresh water has received detailed attention only from the beginning of the last decade (e.g. Krienitz et al., 1996; Padisák et al., 1997). Studies of the molecular diversity of eukaryotic freshwater picoalgae have been carried out on a limited number of isolated strains (Krienitz et al., 1999; Hepperle \& Schlegel, 2002) and the diversity picture is therefore strongly biased from the cultivability of the algae in artificial media.

The phylogenetic analysis, based on 18S rRNA sequences, showed that the most common eukaryotic picoalgae in fresh waters are representatives of the unicellular species Choricystis minor and Myconastes sp. and the colonial Pseudodictyosphaerium jurisii. Some of the unicellular forms can be also found as colonies indicating the capacity of the strains to form microcolonies (Hepperle \& Schlegel, 2002). The commonly used appellation 'Chlorella-like cells' to indicate picoeukaryotic algae is incorrect because Chlorella is larger than $3 \mu \mathrm{m}$ and therefore cannot be included in picophytoplankton (Hepperle \& Schlegel, 2002). The formal inclusion in picophytoplankton of colonial forms, like some Myconastes 
strains or Pseudodictyosphaerium jurisii, can be accepted, as the microcolonies can comprise loose cells functionally included in the picophytoplankton (Padisák et al., 1997). The upper size limit for eukaryotic picophytoplankton is critical, as many taxa have cells in the range $2 \mu \mathrm{m}$ to $5 \mu \mathrm{m}$ : from one point of view, they may be considered small cells but not formally included in the picophytoplankton. For example, vegetative cells of the genus Chlorella may have cell diameters of about $3 \mu \mathrm{m}$, but the autosporangia release cells of $<2 \mu \mathrm{m}$. Such 'borderline' organisms are numerous and the decision to include them or not in the picophytoplankton can affect drastically the quantification of their importance, in terms of numbers and biomass. Furthermore the fixation and pre-filtration steps can alter individual biovolumes (shrinkage and inclusion of larger-size cells) and similarly influence the quantification of the picophytoplankton and the estimation of its importance in the ecosystem (Booth, 1987).

A more realistic approach to the diversity of eukaryotic picophytoplankton is based on the 18S rDNA environmental gene library accumulated from cloning studies on natural samples from different depths or sites. The resulting phylogenetic trees may includeheterotrophic, mixotrophic and autotrophic picoeukaryotes (Lefranc et al., 2005; Richards et al., 2005). Frequently, the size range analysed is not strictly that of picophytoplankton but may extend up to $5 \mu \mathrm{m}$, particularly for fresh waters (Richards et al., 2005). This last-named study suggested that at least some phylogenetic clusters are globally dispersed with some picoeukaryotic lineages being widely distributed.

In coastal waters of the Pacific Ocean, the diversity of the picoeukaryotes smaller than $2 \mu \mathrm{m}$ was recently studied by Warden (2006). The results showed a year-round dominance of picoprasinophytes (Micromonas clades) at the site studied.

New perspectives come from discovery of a new group of marine picoeukaryotes, the picobiliphytes. These contain an organelle-like body (most probably a plastid) that fluoresces orange, indicative of phycobilins, and with a DNA-containing nucleomorph (Not et al., 2007). The use of gene sequencing supports the incidence in natural samples of secondary endosymbioses that considerably increase diversity among the eukaryotic picoplankton (Not et al., 2007).

\section{Picophytoplankton ecology: the current view}

Among the community of aquatic ecologists, there is a general consensus about the ecological role and ecosystem function fulfilled by picophytoplankton. The previously unknown world of pico-sized organisms is now more familiar and single-cell analytical methods have opened 'Alice's tiny door' to the hitherto inaccessible gardens.

Although they contribute to the same size fraction of organisms, the functional ecologies of the various picophytoplankton taxa differ significantly. The origin of size classification of the plankton derives from an approach to the importance of algae as food for larger organisms (packages of carbon and energy of use to grazers). Ecologists were first concerned with carbon fluxes and yields to trophic food chains; in this context, the microbial world received attention for the organic carbon it produces and supplies to an active microbial food web. Such quantification revealed gaps in the understanding of the detailed mechanisms of microbial functioning. In recent years, the emphasis of research has been more directed to single-cell analysis, in order to discern the roles of individual taxa in the carbon budget. Now, the way to engrave the new paradigm in microbial ecology is in the direction of a global view of the phylogenetic function of particular clades that characterise genetically the various ecotypes.

The ecological characteristics of eukaryotic picophytoplankton are more related to the phylogenetic membership of taxa than to their size. The study of eukaryotic picophytoplankton has recently received much attention because molecular techniques have allowed the recognition of undetermined species. The extension of the size range to $5 \mu \mathrm{m}$, to include organisms not otherwise considered in previous ecological studies, has greatly increased the appreciation of their quantitative importance. Genetic studies have considered the autotrophic fraction of the eukaryotic picophytoplankton 
along with heterotrophic and mixotrophic fractions, both in lakes (Lefranc et al., 2005; Richards et al., 2005) and in the sea (Díez et al., 2001; Warden, 2006). Studies reveal that the population abundance of eukaryotic picophytoplankton $(<2 \mu \mathrm{m})$ is generally one order of magnitude less than that of picocyanobacteria, often showing a peak in spring or during summer stratification (Stockner, 1991; Callieri \& Stockner, 2002). Picoeukaryotes have been found to constitute an important fraction in the near-shore station of Lake Baikal (Katano et al., 2005), in boreal humic lakes (Jasser \& Arvola, 2003), in humic Danish lakes (Søndergaard, 1990), in acidic dystrophic lakes (Stockner \& Shortreed, 1991), and in eutrophic shallow lakes (Mózes et al., 2006). The findings of Craig (1987) showed the importance of light by explaining the prevalence of eukaryotic over prokaryotic picophytoplankton in less transparent, eutrophic lakes. Pick \& Agbeti (1991) have found that the contribution of eukaryotic picoplankton to the total picoplanktonic biomass increases with the light extinction coefficient.

In his review of the dynamics of picophytoplankton, Weisse (1993) pointed out that the factors controlling the distribution of eukaryotic pico-cells are different from those that drive the variation of picocyanobacteria in space and time. The review acknowledged that the particular nutritional and light requirements of picocyanobacteria and their potential rates of growth are very different from those of eukaryotic picophytoplankton. Picocyanobacteria comprise the majority of the picophytoplankton of large, deep oligotrophic and mesotrophic lakes, where the maximum occurrence of eukaryotic picophytoplankton is mainly associated with conditions of spring mixing and of nutrient-replete water (Fahnenstiel et al., 1991b; Callieri \& Pinolini, 1995; Passoni et al., 1997). Molecular approaches to the ecological study of picophytoplankton reveal the otherwise widespread occurrence of picocyanobacteria. In Lake Constance (Bodensee), real-time PCR and DGGE were used to trace the closely-related, PE-rich Synechococcus spp. that may each form distinct local subpopulations of picophytoplankton (Becker et al., 2002). In the Arabian Sea, the molecular analysis of picophytoplankton communities revealed a spatial separation of different ecotypes along a horizontal transect (Fuller et al., 2006). Distinct picocyanobacterial lineages thus seem able to arise in particular patches of water having different environmental characteristics (Fuller et al., 2006). A similar deduction was made by Ernst et al. (2003) in relation to picocyanobacterial isolates from subalpine lakes and from the brackish Baltic Sea. The reproduction of different pigment traits in various lineages was not correlated with the phylogenetic divergence but rather seemed to be related to characteristics of the ecosystem and habitat from which the strains were isolated (Ernst et al., 2003). Another recent study on Lake Constance showed that picocyanobacteria from biofilms exhibited much closer phylogenetic relationships to isolates of the pelagic picoplankton than to Synechococcus spp. isolated from hot springs and hypersaline ponds (Becker et al., 2004). Thus, the picocyanobacteria of the cyanobacterial evolutionary lineage VI are not exclusively pelagic organisms but they also colonise periphytic biofilms in the euphotic zone of temperate lakes (Becker et al., 2004). This versatility may be the key feature for the ubiquity of picocyanobacteria clades in aquatic systems.

\section{Main factors influencing assemblage dynamics}

The complex variability of community structure is related to the spectrum of environmental variability, through the modulation of intrinsic factors (basin morphometry, thermal stratification, wind mixing) and such external influences as the fluctuating supply of nutrients (Harris, 1980). The exploitation of the environmental variability by the picoplanktonic community is the result of evolutionary mechanistic adaptation and the interrelation with other primary producers of larger size and with predators. Nevertheless, abiotic factors (temperature, precipitation) provide the primary force that drives temporal variability in species abundance, before even competitive interactions (Houlahan et al., 2007). Adaptation to a changing environment, with phasing of fluctuating events, can subject the community to dominance by the fittest available species. The temporal scale is strictly connected with the spatial scale and the study of the seasonal 
variability in the abundance and activity of picoplankton cannot be correctly interpreted without a good description of the cell response to those external forces that vary within water-column space; Harris' (1980) stimulating perspective emphasises the importance to studying the fundamental periodicity of planktic communities. The ultimate consequence of his contention is that, as the growth rate is coupled to the size spectrum of the cells, the latter underpins the strategy of the community to exploit environmental variability. An example of temporal variability of picophytoplankton is provided by the long-term dynamics of the populations in the large, deep, oligo-mesotrophic subalpine lake, Lake Maggiore (Fig. 4). This lake has regained its former oligotrophic state during the present decade following a period of cultural eutrophication and the subsequent application of restorative measures (Callieri \& Piscia, 2002). Following a sharp reduction in the availability of reactive phosphorus (RP) concentrations in the years 1991-1997, down to quite stable levels, variability in picophytoplankton numbers persists unimpeded. Another similar case is found in Lake Stechlin (Germany), where variability in picophytoplankton numbers is evident at an interannual (1994-2000) scale with increasing total phosphorus (TP) concentrations (Padisák et al., 2003a).

Looking at the long-term dynamics of Lake Maggiore, it appears that factors other than nutrients are at least as important as nutrients in influencing the variability in picophytoplankton structure. Here, I will try to elucidate the role of some of the abiotic and biotic factors which may influence picophytoplankton dynamics.

\section{Lake morphometry, thermal regime, trophic state}

In order to interpret picophytoplankton dynamics in fresh water, it is important to take into consideration first the morphometric characteristics of the lake and the abiotic influences. In terms of the percentages contributed by picoeukaryotes, by PE- and by PC-picocyanobacterial cells, the community composition of the picophytoplankton can depend strongly on lake typology and morphogenesis.

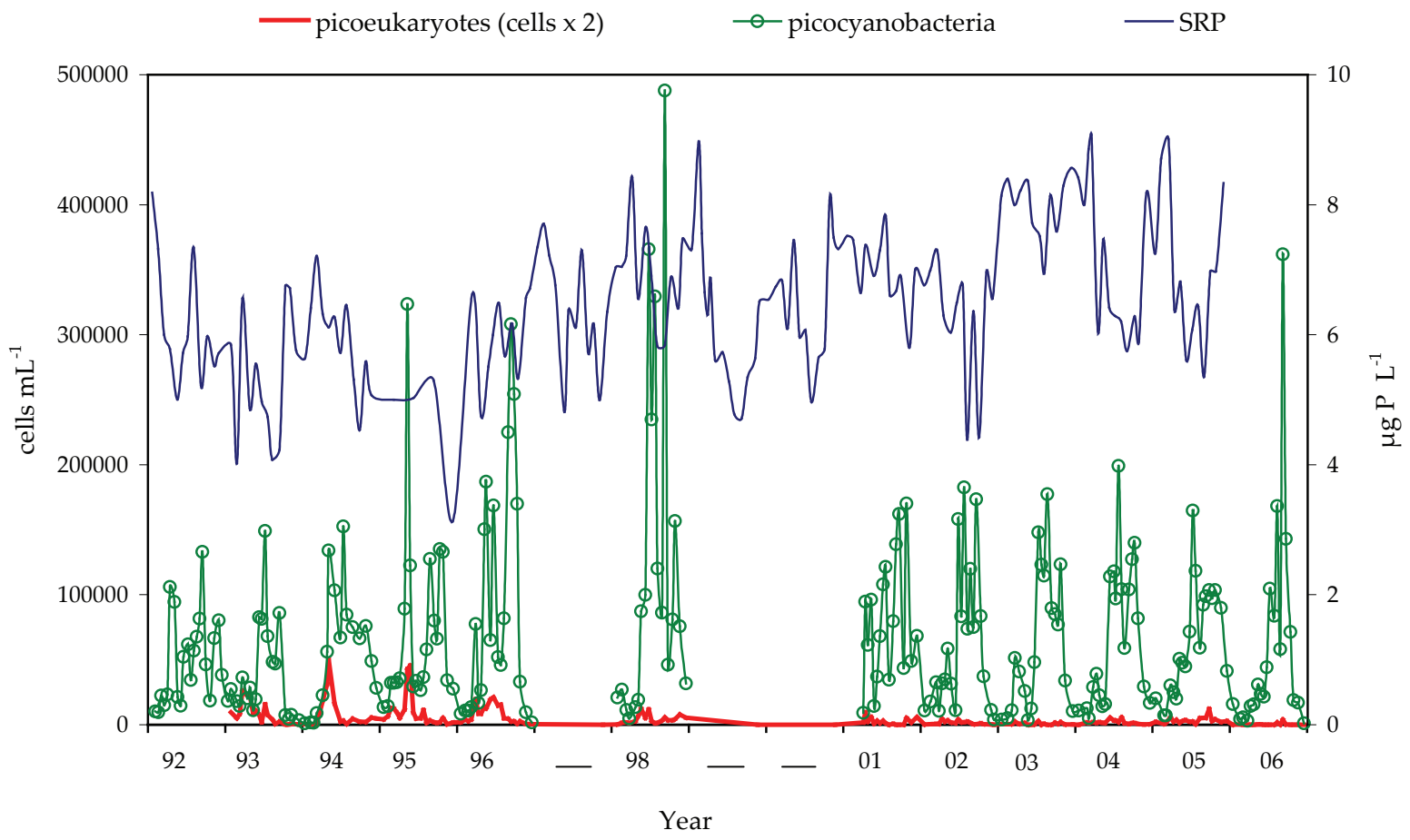

Fig. 4. Long-term dynamics of picophytoplankton in Lake Maggiore (Northern Italy) from 1992 to 2006 and concentration of Soluble Reactive Phosphorus (SRP). 
In a survey covering 43 lakes and ponds, Camacho et al. (2003) found that picocyanobacterial development was favoured by the stability of the vertical structure of the lake (i.e. inertial resistance to complete mixing due to vertical density differences) and by a high hydrological retention time. Large, deep lakes generally constitute preferred environments for the success of picophytoplankton, where maxima generally conform to a typical bimodal pattern, with a spring or early summer peak and a second peak during autumn (Stockner et al., 2000). In Lake Constance (Weisse \& Kenter, 1991; Gaedke \& Weisse, 1998) and Lake Stechlin, Germany (Padisák et al., 1997), the strong influence of the spring mixing period and subsequent stratification are responsible for the interannual variability in picophytoplankton dynamics and the development of a deep-layer maximum. The establishment of a pronounced thermocline at depth favours the development of a deep chlorophyll maximum, constituted by picocyanobacteria which are suited both to the nutrient and light conditions (Modenutti \& Balseiro, 2002; Gervais et al., 1997; Camacho et al., 2003; Callieri et al., 2007). The dynamics of the picophytoplankton are so intimately linked with the abiotic properties that it is sometimes difficult to separate which might be critical. An example of such factor interaction is provided by a study of Lake Maggiore (Callieri \& Piscia, 2002; see also Fig.5), where maximal

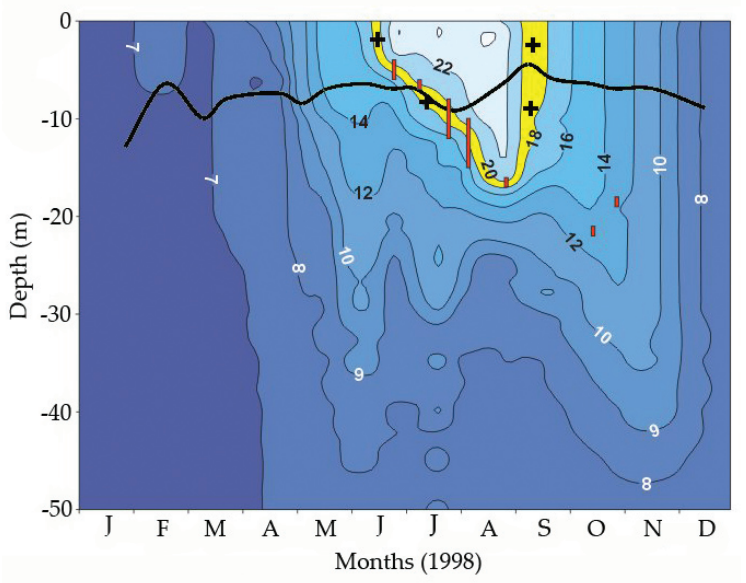

Fig. 5. Isotherm map of Lake Maggiore (Northern Italy), $0 \mathrm{~m}$ to $50 \mathrm{~m}$ layer, during 1998. The crosses indicate the highest values of autotrophic picophytoplankton numbers. Depths with $10 \%$ of surface solar radiation are also given (thick line). Vertical bars indicate themocline extension. (From Callieri \& Piscia, 2002). concentrations of picophytoplankton were observed at an optimum temperature of between $18^{\circ} \mathrm{C}$ and $20^{\circ} \mathrm{C}$ and at the depth of the thermocline. Thermal conditions were important not only for the ambient water temperature per se, but for the maintenance of a density gradient resisting settlement and extension of the picophytoplankton peak. Elsewhere, the peaks of abundance in vertical distribution of picophytoplankton have been observed, variously, in the lower metalimnion and upper hypolimnion of Lake Huron and of Lake Michigan (Fahnenstiel \& Carrick, 1992) and also of Lake Stechlin (Padisák et al., 1998; 2003b); in the metalimnion, beneath the steepest part of the thermocline in Lake Constance and Lake Maggiore (Weisse \& Schweizer, 1991; Callieri \& Pinolini, 1995); in the metalimnion of Lake Baikal (Nagata et al., 1994); and in the epilimnion of Lake Biwa (Maeda et al., 1992), Lake Kinneret (Malinsky-Rushansky et al., 1995) and Lake Alchichia, Mexico (Peštová et al., 2007). If only abiotic parameters are accepted, the variability is incumbent upon the periodicity of the thermal regimes in these otherwise holomictic lakes.

Water column depth, which is roughly inversely related to the trophic state of the lake, is an important indicator of the presence of picophytoplankton and/or of its abundance relative to larger species of phytoplankton. Deep oligotrophic lakes (e.g. the subalpine lakes, the ultraoligotrophic north Patagonian lakes) typically support picophytoplankton comprising mainly PE-cells; PC-cells are quite rare, much as is eukaryotic picophytoplankton. At offshore stations in Lake Baikal, picophytoplankton was constituted by mainly PE-cells, whereas PC-cells and picoeukaryotes were found at a nearshore station (Katano et al., 2005). In the North Patagonian lakes, PE-cells typically dominate the picophytoplankton that forms deep chlorophyll maxima (Callieri et al., 2007; see also Fig. 6).

Picophytoplankton composition and abundance also vary conspicuously among shallow lakes. We may distinguish:

1. shallow, clear oligotrophic lakes (generally mountain lakes);

2. shallow, turbid, eutrophic lakes; and

3. shallow humic lakes. 
In the first category of clear oligotrophic lakes, the picophytoplankton is often negligible and, where present, comprises mostly eukaryotic species. This was a clear finding of the European project MOLAR investigating the microbial food webs of 13 mountain lakes (see Straškrabová et al., 1999, and references sited therein). Picocyanobacteria are low-light adapted microorganisms and are very sensitive to high light intensities and excessive ultra-violet radiation (Callieri et al., 2001). This has been suggested as one possible explanation for their low numbers, or even absence, in such environments. Another factor that may suppress picocyanobacterial growth in mountain lakes is the low $\mathrm{pH}$ common in many of these lakes. In fact, picocyanobacterial numbers have been found to decrease with decreasing $\mathrm{pH}$; below pH 6, they contribute very weakly to the total autotrophic picoplankton community (Stockner \& Shortreed, 1991).

In the second category of shallow, turbid, eutrophic lakes, underwater light quality is influenced by concentrations of organic matter in suspension or solution; in turn, it appears to be one of the main factors influencing the presence of PC- and PE-picocyanobacteria and picoeukaryotes. Picophytoplankton can be present in high concentrations in these lakes, the chemical characteristics of the water protecting them from photoinhibition. Lake Balaton (Hungary) has been well studied for many years (Vörös et al., 1991; Vörös et al., 1998) and provides a typical example of how picophytoplankton can be very sensitive to underwater light climate. In the shallower and turbid (also more eutrophic) areas of this shallow lake, PC-picocyanobacteria prevail over PE- ones but, in winter, eukaryotic forms were found to dominate the picophytoplankton (Mózes et al., 2006). Conversely, PE-cells prevailed over the other forms in the mesotrophic eastern basin.

In the third category of shallow lakes, the staining of water with high concentrations of dissolved humic matter provides, in theory, a suitable environment in

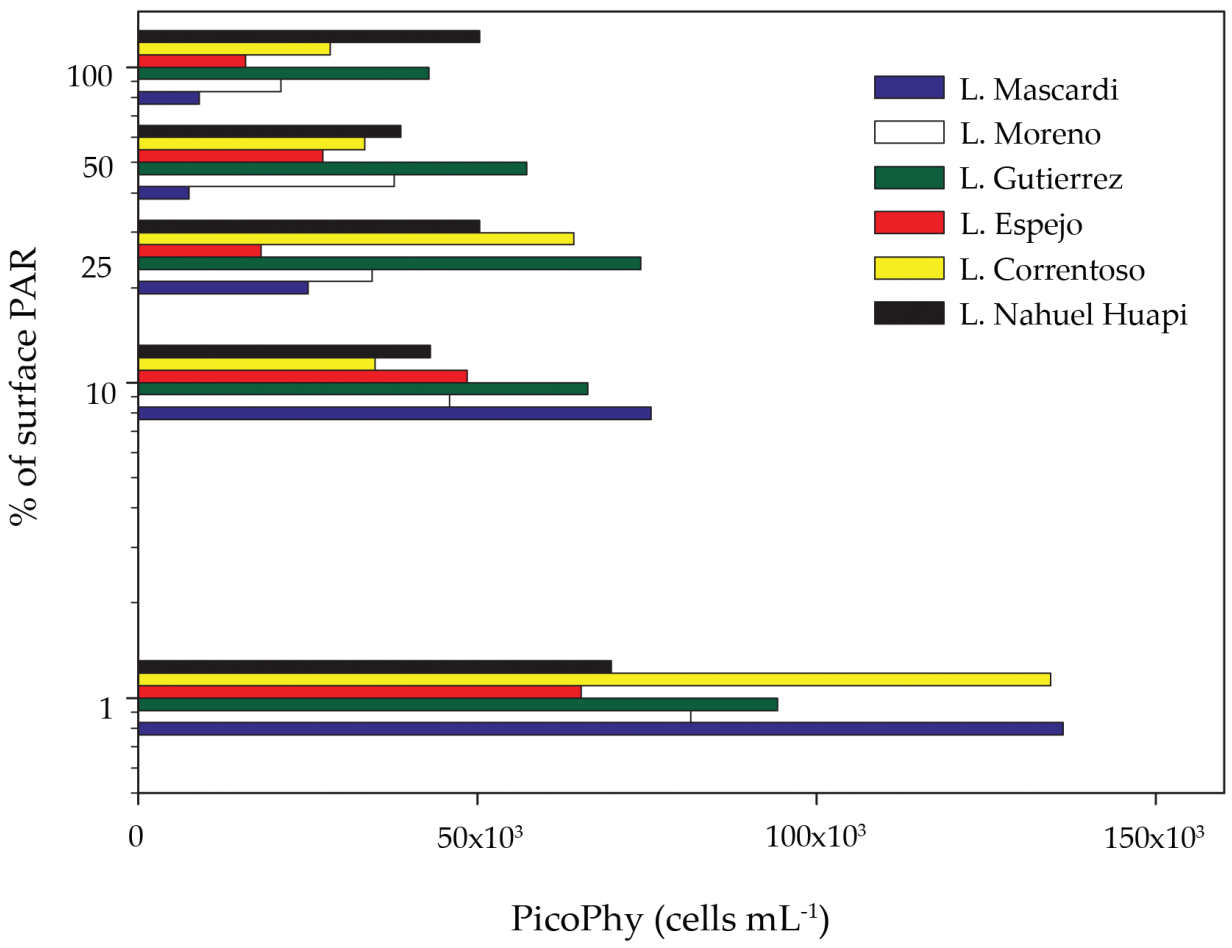

Fig. 6. Vertical distribution of picophytoplankton (PicoPhy) cells along the water column in the ultraoligotrophic Argentinian North Patagonian lakes (PAR: photosynthetically active radiation). 
which picophytoplankton can grow. Furthermore, such environments can be dystrophic, having high concentrations of nutrient elements but with low bioavailabilities, which may also be supposed to favour picophytoplankton. In fact, the occurrence of picophytoplankton in such lakes is quite unpredictable. In a study of shallow humic lakes of the Boreal Forest Zone, Jasser \& Arvola (2003) found picophytoplankton to be lightand temperature limited and that the trophic state was not the characteristic most influencing picophytoplankton composition. On the one hand, other factors such as $\mathrm{pH}$ can be selectively important for the relative abundances of picoeukaryotes and picocyanobacteria; on the other, the coloured organic waters of humic lakes can provide conditions favourable to the growth of bacteria and of mixotrophic flagellates, so that competition within the picoplanktic size fraction is a possibility. A clear trend towards an inverse correlation between the proportion of picophytoplankton and the concentration of DOC (dissolved organic carbon) was detected in the study of humic Swedish lakes of Drakare et al. (2003), who also showed that absolute abundance of picophytoplankton occurred at intermediate DOC concentrations.

Again, the interaction of factors such as nutrient $(C$, $\mathrm{P}, \mathrm{N}$ ) availability, light income, transparency and thermal stability creates conditions that, in different measures, can favour the development of a picophytoplankton. Moreover, picoplanktic communities may adapt to local conditions, making their behaviour less predictable on a long-term basis. Discrepancies among the results of separate authors considering alternative locations may be partly due to an intrinsic inability to find a perfect model for picophytoplankton success in aquatic systems (Stockner et al., 2000). Despite these difficulties, the detailed synthesis of Vörös et al. (1998), based on a large number of available studies, covering a wide range of water bodies and trophic conditions, and enlarged by the inclusion of ultraoligotrophic lakes (Callieri et al., 2007), nevertheless demonstrates an apparent, positive correlation between the numbers of picocyanobacteria and the trophic conditions in the individual lakes. Moreover, the percentage contributions of picocyanobacteria to the total phytoplankton decrease with increasing trophic state (Fig. 7). This model has also been applied to marine ecosystems (Bell \& Kalff, 2001). The progress in picophytoplankton genetics and taxonomy should amplify and authenticate this model and so enhance a developing paradigm of picophytoplankton communities.

\section{Nutrient and light limitation}

In the oligotrophic ocean, nitrogen and iron are considered the main nutrients limiting primary production (Mills et al., 2004). Nevertheless, in the Mediterranean area and in the North Pacific subtropical gyre, a climate-related shift from N- to P-limited ecosystem over the past several decades has been observed (Moore et al., 2005).

Inlakes, primarily phosphorus has been regarded as the limiting nutrient (Schindler, 2006). Recently, by reference to data from the ultraoligotrophic lakes of the Patagonian region of Argentina, Diaz et al. (2007) have demonstrated that nitrogen deficiency, even more than phosphorus, can be the cause of the low productivity. As a matter of fact, we may infer from the Stockner model that the more oligotrophic are the conditions of lakes or oceans, the greater is the probable importance of picophytoplankton relative to other autotrophs (Bell \& Kalff, 2001). Thus, past assumptions about whether the $\mathrm{N}$ or $\mathrm{P}$ is the proximate or ultimate nutrient limiting the productivity of natural picophytoplankton populations in both marine and freshwater systems are re-opened to debate. Laboratory experiments with marine picophytoplankton have demonstrated that for these species, limitation by N, P, Fe or light, although severely restricting growth, does not necessarily mean zero growth (Timmermans et al., 2005).

With particular reference to phosphorus, how much is known about the $\mathrm{P}$ requirements of the cyanobacterial components of picophytoplankton, with what potential competitive advantage over bacteria and larger phytoplankton? We know that Synechococcus spp. have a high affinity for orthophosphate (Moutin et al., 2002) and a maximum cell specific P-uptake rate that is competitively superior to algae and other bacteria under a pulsed supply (Vadstein, 2000). As a matter of fact, 
there are experimental data both from the field and from laboratory experiments that confirm a high capability of picophytoplankton to survive limiting conditions.

An alternative explanation for relative picocyanobacterial success at low $\mathrm{P}$ concentrations is given by the ability of these cells to utilise, in addition, organic sources of phosphate. Under orthophosphate limitation, algae hydrolyse ambient organic phosphates using extracellular phosphatases and transport the orthophosphate thus liberated into their cells (Jansson et al., 1988). The extracellular phosphatase activity (APA) in several phytoplankton species has been demonstrated by the enzyme-labelled fluorescence (ELF) technique (Nedoma et al., 2003; Štrojsová et al., 2003). This technique permits both the quantification of the enzyme produced and the microscopic localisation of the enzyme. Picocyanobacteria can produce alkaline phosphatases under conditions of phosphate starvation (Simon, 1987) but, up to now, none has been observed to show APA-activity using the ELF technique (A. Štrojsová, personal communication). A genetic study on marine strains (Moore et al., 2005) revealed inter-strain variability in the presence and/or absence of genes governing Pacquisition and -scavenging. Such variability might

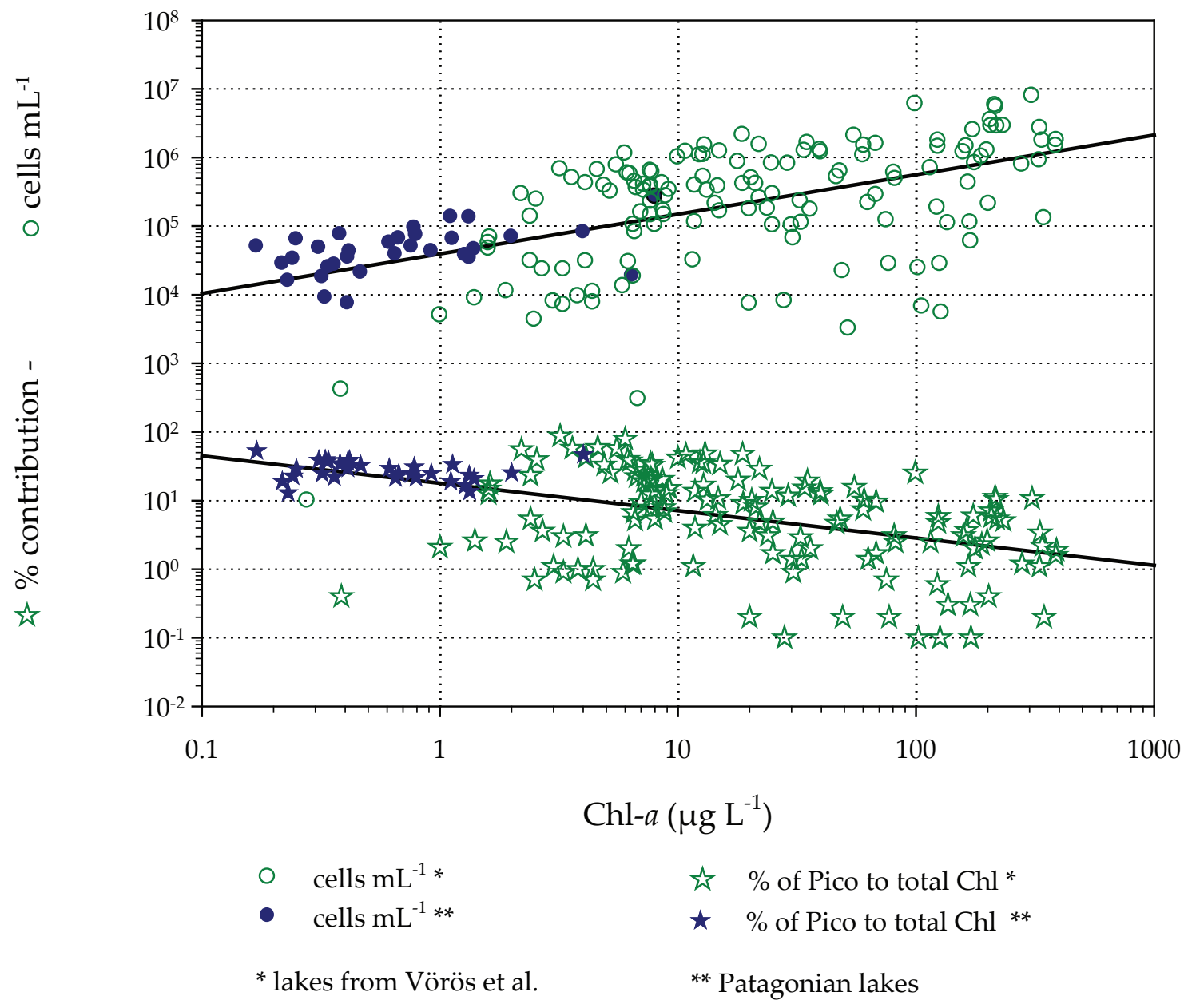

Fig. 7. Relationship between total autotrophic biomass $\left(\mu \mathrm{g} \mathrm{chl}-a \mathrm{~L}^{-1}\right)$ and picophytoplankton abundance and percent biomass contribution to total autotrophic biomass (modified from Vörös et al., 1998). The Patagonian data are from Callieri et al., (2007). 
influence the production of APA and the different reactions of separate strains to low $\mathrm{P}$ concentrations.

Recently, it has been shown that picocyanobacteria (mainly Prochlorococcus) in oligotrophic oceans synthesise SQDG (sulfoquinovosyldiacylglycerol), a lipid that contains sulphur and sugar instead of phosphate (Van Mooy et al., 2006). The ability of Cyanobacteria to substitute sulphate $\left(\mathrm{SO}_{4}^{2-}\right)$ for $\mathrm{PO}_{4}^{3-}$ in lipids, thus minimising their phosphorus requirement by using a 'sulphur-for-phosphorus' strategy, could represent a fundamental biochemical adaptation of picocyanobacteria to dominate severely phosphorusdeficient environments (Van Mooy et al., 2006).

Light is known to be an important factor in niche differentiation for picocyanobacteria. Synechococcus ecotypes exhibit differences in their accessory pigments that affect their adaptation to spectral light quality; however, adaptation to high or low light has not been as thoroughly investigated in Synechococcus strains as it has in the case of Prochlorococcus strains (Ahlgren \& Rocap, 2006). Both in the ocean and in stratifying lakes, the maximum peak abundance of Synechococcus has been found deeper in the water column than that of other species (Callieri \& Pinolini, 1995; Glover et al., 1985; Padisák et al., 1997). Nevertheless its presence in lakes has been confirmed also at other depths with exposure to higher irradiances (e.g. Callieri \& Piscia, 2002). Therefore, the early prevailing hypothesis that Synechococcus strains required low light regimes for growth is no longer consistent with physiological information from pre-acclimated cultures (Kana \& Glibert, 1987). The relative phylogenetic complexity of the Synechococcus and Cyanobium genera do not presently permit the simple discrimination of high light- and low light-adapted ecotypes, as has been attained for Prochlorococcus (Scanlan \& West, 2002). The response of Synechococcus to low light is to increase the ratio of phycobiliprotein to chlorophyll $a$ but there is a diversity of responses among the different strains (Kana \& Glibert, 1987). Phycobiliprotein also serves as a nitrogen store, pending conditions of $\mathrm{N}$ deficiency. The success of picocyanobacteria under low light conditions is tightly coupled with the competition for limiting nutrients. In this way, low-light adaptation in Synechococcus is probably of greatest ecological advantage when low-P conditions constrain the growth of all autotrophs (Wehr, 1993).

The pigment composition of picocyanobacteria represents a characteristic spectral signature that can define individual strains (Everroad \& Wood, 2006). Such signatures have been associated with particular water masses with particular underwater light quality (Wyman \& Fay, 1986; Hauschild et al., 1991; McMurter \& Pick, 1994). Tandeau de Marsac (1977) has pointed out that only Cyanobacteria able to synthesize PE can undergo complementary chromatic adaptation; she distinguished three physiological groups of PE-cells: Group I (with no adaptation); Group II (with regulation of PE); Group III (with regulation of PE and photosynthetic pigment). Marine Synechococcus strains exhibit GroupII chromatic adaptation, being able to increase their phycoerythrin content in growth (Hauschild et al., 1991).

The comparison of the growth response of two freshwater strains of Synechococcus spp., one of PE-cells and the other of PC-cells, demonstrated the selective value of red light in stimulating the PC and in suppressing PE (Callieri et al., 1996). The importance of red light for phycocyanin and biomass production was ascertained in laboratory experiments with a Synechococcus strain of PC-cells (Takano et al., 1995). Blue and green light are used more efficiently than red wavelengths of similar intensity by Synechococcus PE-cells (Glover et al., 1985).

It was found that, in highly coloured lakes, nonphycoerythrin cells dominated numerically whereas, in oligotrophic hard-water lakes, phycoerythrinrich cells were the most abundant (Pick, 1991). The influence of underwater light quality on the selection of picocyanobacterial types having different pigment content has been studied in many lakes, covering a wide spectrum of trophic states and underwater light quality (Callieri, 1996; Vörös et al., 1998). In laboratory experiments, it has been shown that picocyanobacteria grow better when they have a phycobiliprotein whose absorption spectrum is complementary to that of available light (Callieri et al., 1996). A competition model (Stomp et al., 2004), tested using published data from the Pacific Ocean, the Baltic Sea and many lakes 
in Italy, Hungary, Canada, Nepal and New Zealand, proposes that niche differentiation along the spectrum of underwater light conditions offers opportunities to picocyanobacteria for coexistence (Stomp et al., 2007).

\section{Biotic interactions}

Heterotrophic (including mixotrophic) nanoflagellates and small ciliates have been recognised as the most important grazers of picophytoplankton (Stockner \& Antia, 1986; Bird \& Kalf, 1987; Sanders et al., 1989; Weisse, 1990; Christoffersen, 1994; Šimek et al., 1995). Among the ciliates, oligotrich species and some scuticociliates, which are sometimes at the borderline between nano- and microplankton $(<30 \mu \mathrm{m})$, can be important picoplanktivores in lakes (Šimek et al., 1995; Callieri et al., 2002). Large mixotrophic ciliates, common in ultraoligotrophic south Andean lakes, are also recognised as preying upon picocyanobacteria (Modenutti et al., 2003; Balseiro et al., 2004). It has been demonstrated as well that some of the most common freshwater ciliate species can survive on a diet of picoplankton as a sole energy source (Šimek et al., 1996).

A tentative annual balance of energy flow in a deep oligotrophic lake (Callieri et al., 2002) estimated that around $80 \%$ of the carbon produced by picophytoplankton is taken up by protozoa and channelled to metazooplankton. Among protozoa, it was found that heterotrophic nanoflagellates (HNF) are responsible for $90 \%$ of the grazing of picophytoplankton and bacteria, whereas ciliates accounted for only $10 \%$ (Pernthaler et al., 1996a). This proportion is liable to change because it is strongly influenced by the community composition and taxaspecific clearance rates of the consumers (Pernthaler et al., 1996a). For example, a prevalence of choanoflagellates, highly specialised bacterial feeders, in the HNF community, results in a higher consumption of the heterotrophic pico-fraction relative to the autotrophic one.

Šimek et al. (1996) have delimited three ecological categories of freshwater ciliates, according to their feeding strategies and a decreasing importance of pico-size prey in their diets. Among the most efficient suspension feeders are such very active grazers of picoplankton as Vorticella aquadulcis, Halteria grandinella, Cyclidium sp. and Strobilidium hexachinetum (Fig. 8). These protozoa are able to graze between 76 and 560 picophytoplankton cells $\mathrm{h}^{-1}$; raptorial feeders, such as Urotricha and Balanion planktonicum, have rather lower grazing rates ( 0.2 to 2 picophytoplankton cells per hour) (Šimek et al., 1996). The mixotrophic ciliate Ophrydium naumanni ingests picocyanobacteria at a very high rate (clearance rate: 0.35 - $0.60 \mu \mathrm{L} \mathrm{cil}^{-1} \mathrm{~h}^{-1}$, Modenutti \& Balseiro, 2002; Balseiro et al., 2004). Ciliates and HNF can also serve as a trophic link between picocyanobacteria production and Daphnia
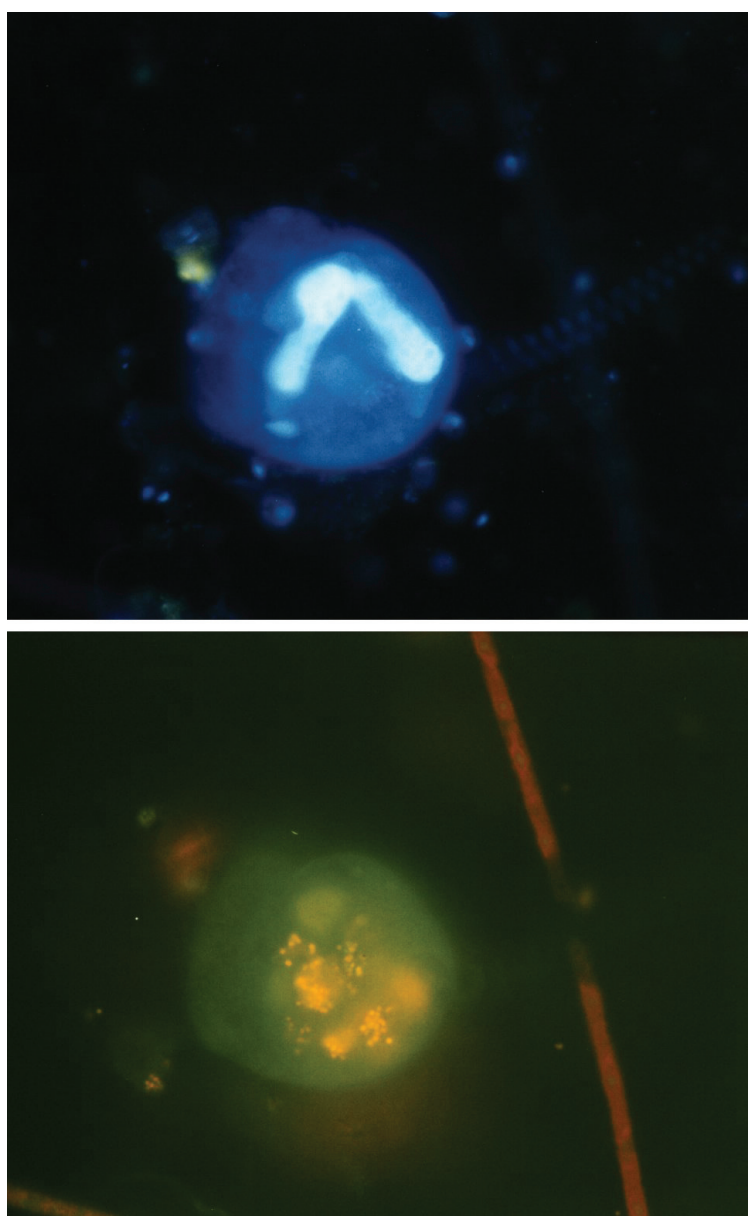

Fig. 8. The ciliate Vorticella sp. coloured with DAPI and visualised under UV (above) and blue (below) excitation (epifluorescence microscope $787.5 \times$ ). In DAPI the nucleus is clearly visible and in blue excitation in the same ciliate the vacuoles full of yellow picocyanobacteria appear. 
production, thereby upgrading the nutritional value of a picocyanobacterial food source by producing essential lipids such as sterols (Martin-Creuzburg et al., 2005; Martin-Creuzburg \& Von Elert, 2006).

The current models of planktic microbial food webs are based on the presence or absence of Daphnia, a winning competitor over protozoa and rotifers for algae (Stockner \& Porter, 1988; Porter et al., 1988). Among mesozooplankton, Daphnia has the capacity of feeding on a wide particle size range $(1 \mu \mathrm{m}$ to $50 \mu \mathrm{m})$, filtering picophytoplankton as well (Gophen \& Geller, 1984; Stockner \& Porter, 1988) (Fig. 9). Together with Daphnia, several cladoceran genera, including Bosmina, Eubosmina and Ceriodaphnia, are able to ingest picocyanobacteria (reviewed by Weisse, 1993). Suspension-feeding cladocerans may have a direct effect on picophytoplankton by grazing and an indirect effect by regenerating nutrients (Carrillo et al., 1996; Balseiro et al., 1997). The recycling of excreted nutrients moves the nature of algal-bacterial interactions from competition to commensalism (Reche et al., 1997). An important effect of Daphnia grazing on picocyanobacteria functioning

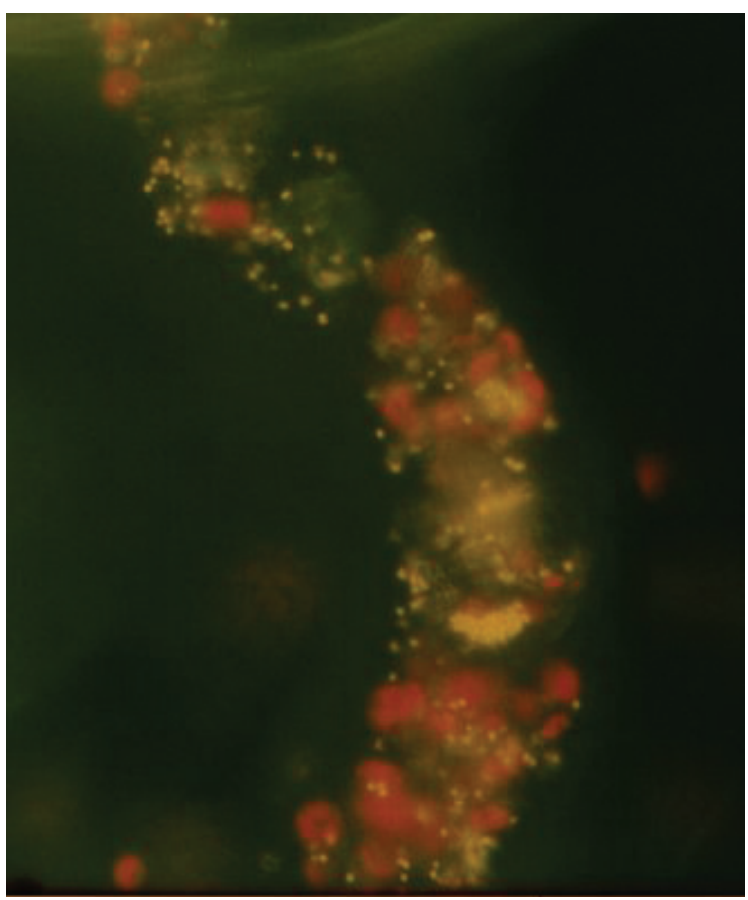

Fig. 9. Daphnia gut passage of picocyanobacteria (yellow) and eukaryotic algae (red) seen under epifluorescence microscopy (787.5×). was observed in laboratory experiments (Callieri et al., 2004), where there was an increase in P and C cell-specific uptake of picocyanobacteria and in their photosynthetic efficiency. This increase in activity could have been related to the release of $\mathrm{P}$ by Daphnia, which was measured to be worth around $5 \%$ of the total P-pool per day (Boersma \& Wiltshire, 2006). Another possible conjecture is that nutrients are replenished during the passage of picocyanobacteria through the digestive tracts of consuming daphnids (Porter, 1975; Stockner, 1991). There is evidence that nutrient-limited green algae pass through the gut of Daphnia intact and alive (Van Donk \& Hessen, 1993) and that during passage some of the $\mathrm{P}$ is released in the gut (Boersma \& Wiltshire, 2006). Recently, it has been found that resistance to digestion is not very important and that an enrichment of green algae by passing through the digestive tract of Daphnia magna is of very limited ecological relevance (Boersma \& Wiltshire, 2006); nevertheless no experiments have been performed with picocyanobacteria.

Planktic rotifers may also graze directly on picophytoplankton (Stockner \& Shortreed, 1989) or otherwise influence their abundance through feeding on HNF: a significant inverse correlation between HNF biomass and rotifer abundance was demonstrated by Pernthaler et al. (1996b). It has been found that many planktic rotifers (Keratella cochlearis, K. quadrata, Polyarthra dolichoptera) feed on particles in the size-range $0.5 \mu \mathrm{m}$ to $3 \mu \mathrm{m}$, interspecific variation in food selection being dependent on differences in the corona sizes of the consuming species (Ronneberger, 1998). As picophytoplankters are within the size range of foods available to the nauplii and early copepodite stages of copepods (Stockner \& Antia, 1986), these crustaceans may also have a bearing on the rates of consumption of picophytoplankton. This possibility has been partly confirmed by the direct estimate of the grazing rate on picocyanobacteria and bacteria by copepod nauplii in the sea (Roff et al., 1995).

Among fresh waters, few studies refer to the impact of copepods, particularly calanoid copepods, on the microbial food web in general or on picophytoplankton in particular. It has been shown that the copepods have a stronger negative effect on ciliates than do Daphnia 
(Burns \& Schallenberg, 1996) and that top-down effects, in the short term, are stronger in oligotrophic ecosystems than in eutrophic ones (Burns \& Schallenberg, 2001). The mesocosm experiments of Zöllner et al. (2003) showed the structuring and cascading effects of the cladoceran Daphnia hyalina $\times$ galeata and copepods (50\% Eudiaptomus spp. and $50 \%$ copepodite stages of cyclopoid copepods) on microbial food web components. The investigators found a decrease in picocyanobacteria that was probably due to the selective feeding of copepods on intermediatesized ciliates and a strong increase in the concentrations of HNF. Copepods prey selectively and efficiently on ciliates and algae in the size range $20 \mu \mathrm{m}$ to $40 \mu \mathrm{m}$ (Yoshida et al., 2001), thereby triggering a trophic cascade, enabling high numbers of HNF and, potentially, depressed numbers of picophytoplankton (Zöllner et al., 2003). Sundt-Hansen et al. (2006) have shown that, in marine mesocosms, copepods have a profound structuring effect on the pelagic food web and, thus, regulate directly and indirectly the abundances of predators of picophytoplankton. In this way, the strength of the trophic cascade downward to picophytoplankton depends substantially on the structure of the food web and the inventory of copepod species present (Gismervik, 2006).

Efforts have also been focused on the direct measurement of grazing and growth rates in situ, to ascertain whether they are in balance or not and how their relative importance varies with changing environmental conditions (Nagata et al., 1994; Nagata et al., 1996; Weisse \& Schweizer, 1991). Overall, it is possible to conclude that grazing losses of picophytoplankton can vary a lot seasonally and are, indeed, closely interrelated to variability in growth rate. The mechanisms that connect grazing to growth could be explained in the light of the changes in individual cells during the diel cycle. The most evident change is in cell volume which increases prior to a division. Monger \& Landry (1992) have demonstrated that clearance rates of prey by consumers (in the prey range $0.7 \mu \mathrm{m}$ to $1.4 \mu \mathrm{m}$ ) increase approximately linearly with prey diameter. Moreover, Pernthaler et al. (1996a) used a selectivity index to demonstrate that picocyanobacteria are ingested preferentially over bacteria by protozoan predators and they interpreted this result as a size effect more than a quality effect. Nevertheless, if the hypothesised size control of grazing preferences is attractive, the possibility of chemosensory selection by predators should not be rejected (Christoffersen, 1994).

While predation has been recognised as an important top-down structural and dynamic control of picocyanobacteria, rather little attention has been directed towards the study of such other ecological interactions as symbiosis (Adams, 2000). In the sea, the cyanobacterial symbionts (or 'cyanobionts': Taylor, 1982) provide an example of protocooperation. A symbiotic relationship between oceanic unicellular Cyanobacteria and a tintinnid, Codonella sp., was demonstrated by Carpenter \& Foster (2002). In an especially interesting study, Foster et al. (2006) used molecular methods to amplify prokaryotic symbiont rRNA sequences from individual marine cells of various marine eukaryotes. The results showed $53 \%$ of a cyanobacterial symbiont to be closely related to Synechococcus sp. and 3\% to Prochlorococcus sp. The same symbiont was capable of forming associations with a variety of organisms, thus opening up the possibility of consortial interconnections. Nevertheless, it must also be recognised that these dinoflagellates, radiolarian and tintinnid symbioses are very low in abundance and generally confined to the upper $50 \mathrm{~m}$ of the ocean.

Another approach to the study of biological interactions is to consider the in situ occurrences of groups of species that share similar requirements or even show protocooperative interaction. The natural co-occurrence and simultaneous increase or decrease in the numbers of some species may indicate the existence of 'functional associations' (Reynolds et al., 2002) which thus help us to interpret and predict their dynamics. The supposition at the base of such associations is that common morphological or physiological properties offer relative dynamic advantages of the component species of the association. Recently, a new association was proposed that comprises Synechococcus spp. and potentially mixotrophic flagellates (e.g. Rhodomonas lacustris, Ceratium hirundinella, Cryptomonas erosa) (Callieri et al., 2006). Cooccurrence of picocyanobacteria and Ceratium spp. has 
been reported from mesotrophic lakes (Kasprzak et al., 2000), from Lake Kinneret (Berman et al., 1992) and Lake Maggiore (Callieri et al., 2006). In the latter lake, a threeyear study showed a phase of co-existence in which the organisms might each benefit from the association, followed by a phase of predation in which one member of the association prevailed over the other (Fig. 10). At low levels of physical and biological disturbance, the cycle can restart with prey recovery driven by nutrient excretion of phagotrophs. The association indicates that assemblages which form a functional group may not only have similar adaptations and requirements, but can exhibit predatorprey interactions. The co-domination of a desirable prey organism, such as Synechococcus with its potential grazers opens up new perspectives on the interaction between the ecological categories of phytoplankton and the components of the microbial food web.
In considering biological interactions, it is opportune to refer to viral infections. The occurrence of viruses that infect Synechococcus is widespread (Mann, 2003) but there have been few attempts to isolate them from either freshwater or marine environments (Suttle, 2000). Cyanophages are ubiquitous in aquatic environments, and can occur at abundances in excess of $10^{6} \mathrm{~mL}^{-1}$ (Suttle, 2000). Other approaches have been used to infer the effect of viruses on cyanobacterial mortality. Among these, three have been particularly effective in revealing the incidence of infected cells and the host-cell resistance:

1. direct examination by transmission electron microscopy (Proctor \& Fuhrman, 1990);

2. diagnosis of the contact rates between viruses and potential host cells (Waterbury \& Valois, 1993; Mann, 2003); and,

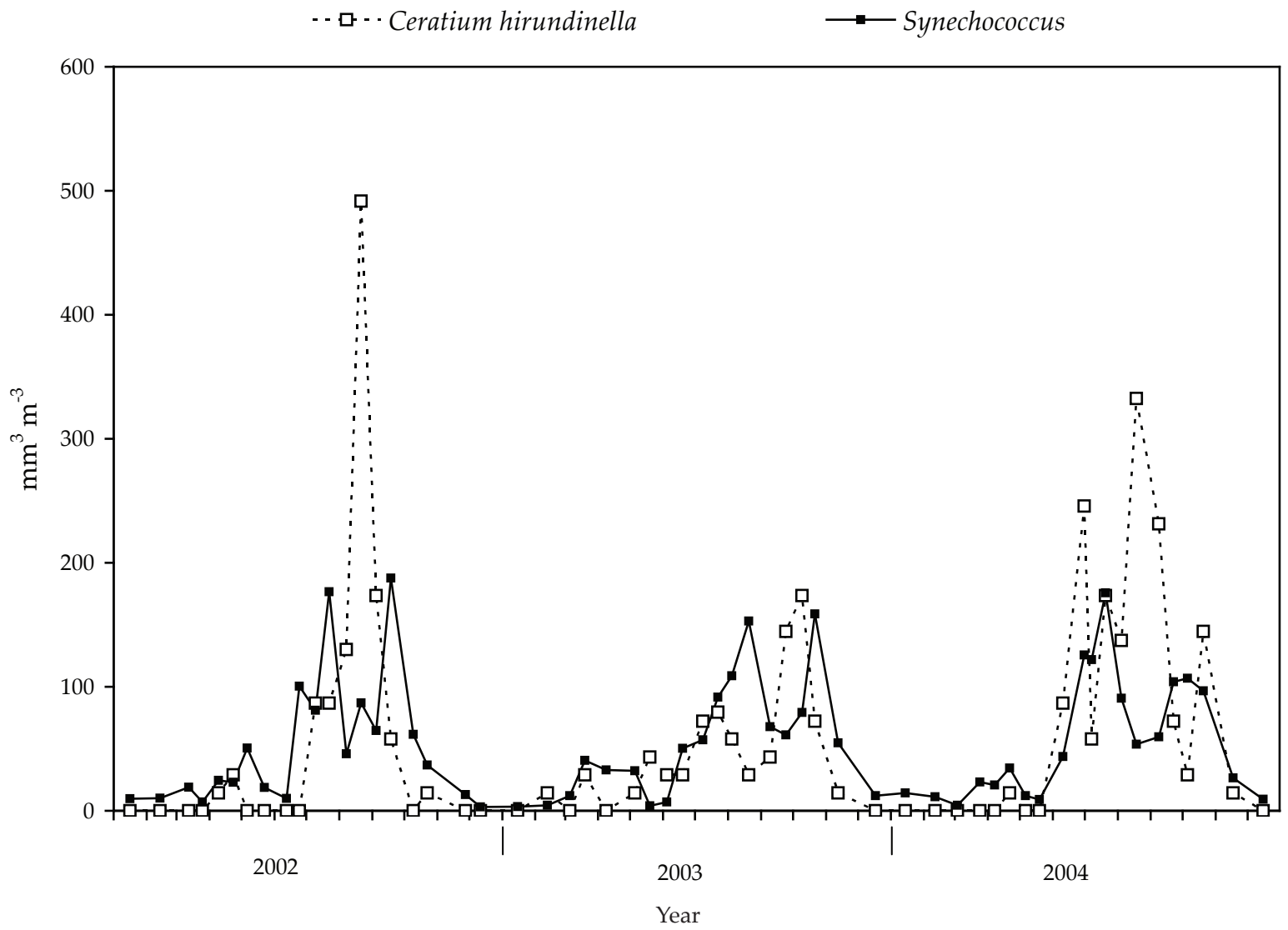

Fig. 10. Seasonal dynamics $(2002,2003,2004)$ of the Synechococcus spp. - Ceratium hirundinella functional association (from Callieri et al., 2006). 
3. calculation of decay rates as a surrogate of mortality (Suttle \& Chen, 1992).

Recent findings indicate that cyanophage infections can effect a major influence on the direction of picophytoplankton succession in the sea (Muhling et al., 2005), and that marine viruses can act as intermediates for exchanging genes (Zeidner et al., 2005).

It is interesting to note the changing perceptions of viruses in recent years: no longer are they seen as universally pernicious parasites but as catalysts of information transfer and sustainers of the microbial web of energy transfer and matter cycling (Weinbauer, 2004).

\section{Conclusions}

The most profound changes in the perception of the importance of picophytoplankton over the last fifteen years have come largely from the enhanced comprehension of the phylogenetic evolution of its components. The new paradigms of microbial ecology are founded on a global appreciation of functionally evolving clades and genetically definable ecotypes. Taxonomic studies of phenotypic diversity are now coupled with genotypic diagnoses that confirm whether similar phenotypes are phyletically close or whether they owe to convergent evolution. Both in marine and freshwater research, effort is strongly directed towards the study of the eukaryotic fraction of picoplankton, including organisms that are variously autotrophic, mixotrophic and heterotrophic. Some of the 'undetermined species', particularly among flagellates, are now classified and their comparative roles among waters of differing trophic states are beginning to be quantified.

The two genera Synechococcus and Cyanobium dominate the prokaryotic picophytoplankton of fresh waters; Prochlorococcus prevails in the oceans. The phylogenetic analysis of the $16 \mathrm{~S} \mathrm{rDNA}$ sequences indicates that, in either case, the unicellular representatives of the cyanobacterial order Chroococcales are polyphyletic and dispersed among the Cyanobacteria. Despite uncertainties about the phylogenetic evolution of Synechococcus, we know that:
1. at least six to seven clusters of non-marine picocyanobacteria have been found within the picophytoplankton clade;

2. that the PE-cells spectral phenotype does not appear to be a general character that can be used to define a clade; and

3. that the Synechococcus-like form may represent an ancestral morphology, from which the other types have evolved.

Lake typology and morphogenesis influence picophytoplankton community composition in terms of the proportional representation of picoeukaryotes and of PE- and PC-picocyanobacteria. Light is known to be an important factor in niche differentiation of picocyanobacteria. Water column depth, which is roughly inversely related to the trophic state of the lake, is an important indicator of picophytoplankton presence and/ or its abundance relative to larger phytoplankton. The percentage of the total phytoplankton mass contributed by picocyanobacteria increases with decreasing trophic state. This can be explained by the high affinity of Synechococcus for orthophosphate. A further explanation for the success of picocyanobacteria at low $\mathrm{P}$ concentrations is the 'sulphur-for-phosphorus' strategy, which is based on the ability of these Cyanobacteria to substitute sulphate for phosphate in lipids. In general, abiotic factors conducive to picophytoplankton success are additive, so that it is difficult to indicate which are the most effective.

Top-down control of picophytoplankton is mainly exerted through the activities of heterotrophic and mixotrophic nanoflagellates and small ciliates. Nevertheless, suspension-feeding cladocerans are also important, both directly, by grazing on picophytoplankton, and indirectly, by regenerating nutrients from their other foods. Knowledge of other types of biological interaction involving picophytoplankton, is not well developed. The prevalence of symbiosis and parasitism has yet to be established. The roles of cyanobionts and cyanophages in the aquatic environments, both as catalysts of information transfer and sustainers of the microbial web of energy transfer and matter cycling, provide exciting subjects for ongoing biological investigations of the picophytoplankton. 


\section{Acknowledgements}

I thank all my staff, students and technicians who have helped me in the collection and analysis of picophytoplankton data. I am also indebted to colleagues who have shared with me the problems of picophytoplankton research in past years: Lajos Vörös, John Stockner, Jaroslav Vrba, Miroslav Macek, Beatriz Modenutti, Esteban Balseiro, Thomas Weisse. The manuscript has been improved in terms of English style thanks to the tireless Editor, Colin Reynolds. Last but not least, I record my infinite thanks to my husband and colleague Roberto Bertoni, who has encouraged me in the struggle to be concerned with science.

\section{References}

Adams, D.G. (2000). Symbiotic interactions. In: The Ecology of Cyanobacteria: their Diversity in Time and Space (eds B. Whitton \& M. Potts), pp. 523-561. Kluwer Academic Publishers, The Netherlands.

Ahlgren, N.A. \& Rocap, G. (2006). Culture isolation and cultureindependent clone libraries reveal new marine Synechococcus ecotypes with distinctive light and $\mathrm{N}$ physiologies. Applied and Environmental Microbiology 72, 7193-7204.

Avaniss-Aghajani, E., Jones, K., Chapman, D. \& Brunk, C. (1994). A molecular technique for identification of bacteria using small subunit ribosomal RNA sequences. BioTechniques 17, 144-149.

Bailey-Watts, A.E., Bindloss, M.E. \& Belcher, J.H. (1968). Freshwater primary production by a blue-green alga of bacterial size. Nature 220, 1344-1345.

Balseiro, E.G., Modenutti, B.E. \& Queimaliños, C.P. (1997). Nutrient recycling and shiftsin N:Pratioby differentzooplanktonstructures in a South Andes lake. Journal of Plankton Research 19, 805-817.

Balseiro, E.G., Queimaliños, C. \& Modenutti, B.E. (2004). Grazing impact on autotrophic picoplankton in two south Andean lakes (Patagonia, Argentina) with different light:nutrient ratios. Revista Chilena de Historia Natural 77, 73-85.

Becker, S., Fahrbach, M., Böger, P. \& Ernst, A. (2002). Quantitative tracing, by Taq nuclease assays, of a Synechococcus ecotype in a highly diversified natural population. Applied and Environmental Microbiology 68, 4486-4494.
Becker, S., Singh, A.K., Postius, C., Böger, P. \& Ernst, A. (2004). Genetic diversity and distribution of periphytic Synechococcus spp. in biofilms and picoplankton of Lake Constance. FEMS Microbiology Ecology 49, 181-190.

Bell, T. \& Kalff, L. (2001). The contribution of picophytoplankton in marine and freshwater systems of different trophic status and depth. Limnology \& Oceanography 46, 1243-1248.

Berman, T., Yacobi, Y.Z. \& Pollingher, U. (1992). Lake Kinneret phytoplankton: Stability and variability during twenty years (1970-1989). Aquatic Sciences 54, 104-127.

Bird, D.J. \& Kalff, J. (1987). Algal phagotrophy: regulating factors and importance relative to photosynthesis in Dinobryon (Chrysophyceae). Limnology \& Oceanography 32, 277-284.

Boersma, M. \& Wiltshire, K. (2006). Gut passage of phosphoruslimited algae through Daphnia: do they take up nutrients in the process? Archiv für Hydrobiologie 167, 498-500.

Booth, B.C.(1987). The use of autofluorescence for analysing oceanic phytoplankton communities. Botanica Marina 30, 101-108.

Burger-Wiersma, T. (1991). Prochlorothrix hollandica: a filamentous prokaryotic species containing chlorophylls $a$ and $b$. Algological Studies 64, 555-558.

Burger-Wiersma, T., Veenhuis, M., Korhals, H.J., van der Wiel, C.C.M. \& Mur, L.R. (1986). A new prokaryote containing chlorophylls $a$ and $b$. Nature 320, 262-264.

Burns, C.W. \& Schallenberg, M. (1996). Relative impacts of copepods, cladocerans and nutrients on the microbial food web of a mesotrophic lake. Journal of Plankton Research 18, 683-714.

Burns, C.W. \& Schallenberg, M. (2001). Short-term impacts of nutrients, Daphnia, and copepods on microbial food-webs on an oligotrophic and eutrophic lake. New Zealand Journal of Marine and Freshwater Research 35, 695-710.

Callieri, C. (1996). Extinction coefficient of red, green and blue light and its influence on picocyanobacterial types in lakes at different trophic levels. Memorie dell'Istituto italiano di Idrobiologia $54,35-142$.

Callieri, C. \& Pinolini, M.L. (1995). Picoplankton in Lake Maggiore, Italy. International Revue der gesamten Hydrobiologie 80, 491-501.

Callieri, C. \& Piscia, R. (2002). Photosynthetic efficiency and seasonality of autotrophic picoplankton in Lago Maggiore after its recovery. Freshwater Biology 47, 941-956.

Callieri, C. \& Stockner, J.G. (2002). Freshwater autotrophic picoplankton: a review. Journal of Limnology 61, 1-14. 
Callieri, C., Amicucci, E., Bertoni, R. \& Vörös, L. (1996). Fluorometric characterization of two picocyanobacteria strains from different underwater light quality. International Revue der gesamten Hydrobiologie 81, 13-23.

Callieri, C., Morabito, G., Huot, Y., Neal, P. \& Lichman, E. (2001). Photosynthetic response of pico- and nanoplanktonic algae to UVB, UVA and PAR in a high mountain lake. Aquatic Sciences 63, 286-293.

Callieri, C., Karjalainen, S.M. \& Passoni, S. (2002). Grazing by ciliates and heterotrophic nanoflagellates on picocyanobacteria in Lago Maggiore, Italy. Journal of Plankton Research 24, 785-796.

Callieri, C., Balseiro, E., Bertoni, R., \& Modenutti, B. (2004). Picocyanobacteria photosynthetic efficiency under Daphnia grazing pressure. Journal of Plankton Research 26, 1471-1477.

Callieri, C., Caravati, E., Morabito, G. \& Oggioni, A. (2006). The unicellular freshwater cyanobacterium Synechococcus and mixotrophic flagellates: evidence for a functional association in an oligotrophic, subalpine lake. Freshwater Biology 51, 263-273.

Callieri, C., Modenutti, B., Queimaliños, C., Bertoni, R. \& Balseiro, E. (2007). Production and biomass of picophytoplankton and larger autotrophs in Andean ultraoligotrophic lakes: differences in light harvesting efficiency in deep layers. Aquatic Ecology 41, 511-523.

Camacho, A., Miracle, M.R. \& Vicente, E. (2003). Which factors determine the abundance and distribution of picocyanobacteria in inland waters? A comparison among different types of lakes and ponds. Archiv für Hydrobiologie 157, 321-338.

Campbell, L., Nolla, H.A. \& Vaulot, D. (1994). The importance of Prochlorococcus to community structure in the Central North Pacific Ocean. Limnology \& Oceanography 39, 954-961.

Caron, D.A., Pick, F.R. \& Lean, D.R.S. (1985). Chroococcoid cyanobacteria in Lake Ontario: seasonal and vertical distribution during 1982. Journal of Phycology 21, 171-175.

Carpenter,E.J.\&Foster,R.A.(2002). Marinesymbioses. In:Cyanobacteria in Symbiosis (eds A.N. Rai, B. Bergman \& U. Rasmussen), pp. 11-18. Kluwer Academic Publisher, The Netherlands.

Carrillo, P., Reche, I. \& Cruz-Pizarro, L. (1996). Quantification of the phosphorus released by zooplankton in an oligotrophic lake (La Caldera, Spain) - Regulating factors and adjustment to theoretical-models. Journal of Plankton Research 18, 1567-1586.

Chisholm, S.W., Olson, R.J., Zettler, E.R., Goericke, R., Waterbury, J.B. \& Welschmeyer, N.A. (1988). A novel free living prochlorophyte abundant in the oceanic euphotic zone. Nature
334, 340-343.

Corzo, A., Jiménez-Gómez, F., Gordillo, F.J.L., García-Ruíz, R. \& Niel, F.X. (1999). Synechococcus and Prochlorococcus-like populations detected by flow cytometry in a eutrophic reservoir in summer. Journal of Plankton Research 21, 1575-1581.

Craig, S.R. (1987). The distribution and contribution of picoplankton to deep photosynthetic layers in some meromictic lakes. Acta Academiae Aboensis 47, 55-81.

Christoffersen, K. (1994). Variation of feeding activities of heterotrophic nanoflagellates on picoplankton. Marine Microbial Food Webs 8, 111-123.

Crosbie, N.D., Pöckl, M. \& Weisse, T. (2003a). Rapid establishment of clonal isolates of freshwater autotrophic picoplankton by single-cell and single-colony sorting. Journal of Microbiological Methods 55, 361-370.

Crosbie, N.D., Teubner, K. \& Weisse, T. (2003b). Flow-cytometric mapping provides novel insights into the seasonal and vertical distributions of freshwater autotrophic picoplankton. Aquatic Microbial Ecology 33, 53-66.

Crosbie, N.D., Pöckl, M. \& Weisse, T. (2003c). Dispersal and phylogenetic diversity of nonmarine picocyanobacteria, inferred from 16S rRNA gene and cpcBA-intergenic spacer sequence analyses. Applied Environmental Microbiology 69, 5716-5721.

Daley, R.J., \& Hobbie, J.E. (1975). Direct counts of aquatic bacteria by a modified epifluorescence technique. Limnology $\mathcal{E}$ Oceanography 20, 875-882.

Diamond, R.A. \& DeMaggio, S. (2000). In Living Color. Protocols in Flow Cytometry and Cell Sorting. Springer-Verlag, Berlin. 800 pp.

Diaz, M., Pedrozo, F., Reynolds, C. \& Temporetti, P. (2007). Chemical composition and the nitrogen-regulated trophic state of Patagonian lakes. Limnologica 37,17-27.

Díez, B., Pedrós-Alió, C. \& Massana, R. (2001). Study of genetic diversity of eukaryotic picoplankton in different oceanic regions by small-subunit rRNA gene cloning and sequencing. Applied and Environmental Microbiology 67, 2932-2941.

Drakare, S., Blomqvist, P., Bergström, A.K. \& Jansson, M. (2003). Relationships between picophytoplankton and environmental variables in lakes along a gradient of water colour and nutrient content. Freshwater Biology 48, 729-740.

Dussart, B.H. (1965). Les différentes catégories de plancton. Hydrobiologia 26, 72-74.

Ernst, A. (1991). Cyanobacterial picoplankton from Lake 
Constance I. Isolation by fluorescence characteristics. Journal of Plankton Research 13, 1307-1312.

Ernst, A., Becker, S., Wollenzien, V.I.A. \& Postius, C. (2003). Ecosystem dependent adaptive radiations of picocyanobacteria inferred from 16S rRNA and ITS-1 sequence analysis. Microbiology 149, 217-228.

Everroad, R.C. \& Wood, A.M. (2006). Comparative molecular evolution of newly discovered picocyanobacterial strains reveals a phylogenetically informative variable region of $\beta$ phycoerythrin. Journal of Phycology 42,1300-1311.

Fahnenstiel, G.L. \& Carrick, H.J. (1992). Phototrophic picoplankton in lakes Huron and Michigan: abundance, distribution, composition and contribution to biomass and production. Canadian Journal of Fisheries and Aquatic Sciences 49, 379-388.

Fahnenstiel, G.L., Carrick, H.J., Rogers, C.E. \& Sicko-Goad, L. (1991a). Red fluorescing phototrophic picoplankton in the Laurentian Great Lakes: what are they and what are they doing? International Revue der gesamten Hydrobiologie 76, 603-616.

Fahnenstiel, G.L., Carrick, H.J. \& Iturriaga, R.(1991b). Physiological characteristics and food web dynamics of Synechococcus in Lakes Huron and Michigan. Limnology \& Oceanography 36, 219-234.

Fogg, G.E. (1986). Picoplankton. Proceeding Royal Society London (B) $228,1-30$.

Foster, R.A., Collier, J.L. \& Carpenter, E.J. (2006). Reverse transcription PCR amplification of cyanobacterial symbiont $16 \mathrm{~S}$ rRNA sequences from single non-photosynthetic eukaryotic marine planktonic host cells. Journal of Phycology 42, 243-250.

Fuller, N.J., Tarran, G.A., Yallop, M., Orcutt, K.M. \& Scanlan, D.J. (2006). Molecular analysys of picocyanobacterial community structure along an Arabian sea transect reveals distinct spatial separation of lineages. Limnology \& Oceanography 51, 2515-2526.

Gaedke, U. \& Weisse, T. (1998). Seasonal and interannual variability of picocyanobacteria in Lake Costance. Archiv für Hydrobiologie 53, 143-158.

Gervais, F., Padisák, J. \& Koschel, R. (1997). Do light quality and low phosphorus concentration favour picocyanobacteria below the thermocline of the oligotrophic Lake Stechlin? Journal of Plankton Research 19, 771-781.

Gismervik, I. (2006). Top-down impact by copepods on ciliate numbers and persistence depends on copepod and ciliate species composition. Journal of Plankton Research 28, 499-507.

Glover, H.E., Phinney, D.A. \& Yentsch, C.S. (1985). Photosynthetic characteristics of picoplankton compared with those of larger phytoplankton populations, in various water masses in the Gulf of Maine. Biological Oceanography 3, 223-248.

Goericke, R. \& Repeta, D.J. (1993). Chlorophylls $a$ and $b$ and divinyl chlorophylls $a$ and $b$ in the open subtropical North Atlantic Ocean. Marine Ecology Progress Series 101, 307-313.

Gophen, M. \& Geller, W. (1984). Filter mesh size and food particle uptake by Daphnia. Oecologia 64, 408-412.

Harris, G.P. (1980). Temporal and spatial scales in phytoplankton ecology. Mechanisms, methods, models and management. Canadian Journal of Fisheries and Aquatic Sciences 37, 877-900.

Hauschild, C.A., McMurter, H.J.G. \& Pick, F.R. (1991). Effect of spectral quality on growth and pigmentation of picocyanobacteria. Journal of Phycology 27, 698-702.

Hepperle, D. \&Schlegel, I. (2002). Molecular diversity of eukaryotic picoalgae from three lakes in Switzerland. International Review of Hydrobiology 87, 1-10.

Holmes, R.W. \& Anderson, G.C. (1963). Size fractionation of 14C labelled natural phytoplankton communities. In: Symposium on Marine Microbiology (ed. C.H. Oppenheimer), pp. 241-250. Thomas, Springfield, Ill.

Houlahan, J.E., Currie, D.J., Cottenie, K., Cumming, G.S., Ernest, S.K.M., Findlay, C.S., Fuhlendorf, S.D., Gaedke, U., Legendre, P., Magnuson, J.J., McArdle, B.H., Muldavin, E.H., Noble, D., Russell, R., Stevens, R.D., Willis, T.J., Woiwod, I.P. \& Wondzell S.M. (2007). Compensatory dynamics are rare in natural ecological communities. PNAS Proceedings of the National Academy of Sciences 104, 3273-3277.

Hutchinson, G.E. (1967). A Treatise on Limnology, II. Introduction to Lake Biology and the Limnoplankton. John Wiley \& Sons, NY. 1115 pp.

Jansson, M., Olsson, H. \& Pettersson, K. (1988). Phosphatases; origin, characteristic and function in lakes. Hydrobiologia 170, 157-175.

Jasser, I. \& Arvola, L. (2003). Potential effects of abiotic factors on the abundance of autotrophic picoplankton in four boreal lakes. Journal of Plankton Research 25, 873-883.

Jezberová,J.\&Komárková,J.(2007). Morphological transformation in a freshwater Cyanobium sp. induced by grazers. Environmental Microbiology 9, 1858-1862.

Johnson, P.W. \& Sieburth, J. McN. (1979). Chrococcoid cyanobacteria in the sea: a ubiquitous and diverse phototrophic biomass. Limnology \& Oceanography 24, 928-935.

Johnson, P.W. \& Sieburth, J. McN. (1982). In-situ morphology 
and occurrence of eukaryotic phototrophs of bacterial size in the picoplankton of estuarine and oceanic waters. Journal of Phycology 18, 318-327.

Kana, T.M. \& Glibert, P.M. (1987). Effect of irradiances up to 2000 $\mu \mathrm{E} \mathrm{m} \mathrm{m}^{-2} \mathrm{~s}^{-1}$ on marine Synechococcus WH7803 -II. Photosynthetic responses and mechanisms. Deep Sea Research 34, 497-516.

Kasprzak, P., Gervais, F., Adrian, R., Weiler, W., Radke, R., Jaeger, I., Riest, S., Siedel, U., Schneider, V., Boehme, M., Eckmann, R. \& Walz, N. (2000). Trophic characterization, pelagic food web structure and comparison of two mesotrophic lakes in Brandenburg (Germany). Internationale Reoue der gesamten Hydrobiologie 85, 167-189.

Katano, T., Nakano, S., Ueno, H., Mitamura, O., Anbutsu, K., Kihira, M., Satoh, Y., Druker, V. \& Sugiyama, M. (2005). Abundance, growth and grazing loss rates of picophytoplankton in Barguzin Bay, Lake Baikal. Aquatic Ecology 39, 431-438.

Kiørboe, T. \& Hansen, J. (1993). Phytoplankton aggregate formation: observations of patterns and mechanisms of cell sticking and the significance of exopolymeric material. Journal of Plankton Research 15, 993-1018.

Komárek, J., Cepák, V., Kaštovský, J. \& Sulek J. (2004). What are the cyanobacterial genera Cyanothece and Cyanobacterium? Contribution to the combined molecular and phenotype taxonomic evaluation of cyanobacterial diversity. Algological Studies 113, 1-36.

Komárková, J. (2002). Cyanobacterial picoplankton and its colonial formations in two eutrophic canyon reservoirs (Czech Republic). Archiv für Hydrobiologie 154, 605-623.

Krienitz, L., Huss, V.A.R. \& Hümmer, C. (1996). Picoplanktonic Choricystis species (Chlorococcales, Chlorophyta) and problems sorrounding the morphologically similar 'Nannochloris-like algae'. Phycologia 35, 332-341.

Krienitz,L., Takeda,H.\&Hepperle,D.(1999). Ultrastucture, cellwall composition and phylogenetic position of Pseudodictyosphaerium jurisii (Chlorophyta, Chlorococcales) in comparison to other picoplanktonic green algae. Phycologia 38, 100-107.

Lefranc, M., Thénot, A., Lepère, C. \& Debroas, D. (2005). Genetic diversity of small eukaryotes in lakes differing by their trophic status. Applied and Environmental Microbiology 71, 5935-5942.

Li, W.K.W., Subba Rao, D.V., Harrison, W.G., Smith, J.C., Cullen, J.J., Irwin, B. \& Platt, T. (1983). Autotrophic picoplankton in the tropical ocean. Science 219, 292-295.
Lohmann, H. (1911). Über das Nannoplankton und die zentrifugierung kleinsten Wasseproben zur Gewinnung desselben in lebendem Zustande. Internationale Revue der gesamten Hydrobiologie und Hydrographie 4, 1-38.

Maeda, H., Kawai, A. \& Tilzer, M.M. (1992). The water bloom of cyanobacterial picoplankton in Lake Biwa, Japan. Hydrobiologia 248, 93-103.

Malinsky-Rushansky, N., Berman, T. \& Dubinsky, Z. (1995). Seasonal dynamics of picophytoplankton in Lake Kinneret, Israel. Freshwater Biology 34, 241-254.

Mann, N.H. (2003). Phages of marine cyanobacterial picophytoplankton. FEMS Microbiology Reviews 27, 17-34.

Margalef, R. (1955). Los Organismos Indicadores en la Limnologia. Biologia de las Aguas Continentales. XII. Ministerio de Agricult. Inst. Forest. Invest. Exper., Madrid. 300 pp.

Martin-Creuzburg, D. \& Von Elert, E. (2006). Trophic upgrading of autotrophic picoplankton by the heterotrophic nanoflagellate Paraphysomonas sp. Limnology \& Oceanography 51, 1699-1707.

Martin-Creuzburg, D., Bec, A. \& Von Elert, E. (2005). Trophic upgrading of picocyanobacterial carbon by ciliates for nutrition of Daphnia magna. Aquatic Microbial Ecology 41, 271-280.

McMurter, H.J.C. \& Pick, F. (1994). Fluorescence characteristics of a natural assemblage of freshwater picocyanobacteria. Journal of Plankton Research 16, 911-925.

Mills, M.M., Ridame, C., Davey, M., La Roche, J. \& Geider, R.J. (2004). Iron and phosphorus co-limit nitrogen fixation in the eastern tropical North Atlantic. Nature 429, 292-294.

Modenutti, B.E., \& Balseiro, E.G. (2002). Mixotrophic ciliates in an Andean lake: dependence on light and prey of an Ophrydium naumanni population. Freshwater Biology 47, 121-128.

Modenutti, B.E., Queimaliños, C., Balseiro, E.G. \& Reissig, M. (2003). Impact of different zooplankton structures on the microbial food web of a South Andean oligotrophic lake. Acta Oecologica 24, S289-S298.

Monger, B.C. \& Landry, M.R. (1992). Size-selectivity grazing by heterotrophic nanoflagellates: an analysis using live-stained bacteria and dual-beam flow cytometry. Archiv für Hydrobiologie 37, 173-185.

Moore, L.R., Ostrowski, M., Scanlan, D.J., Feren, K. \& Sweetsir, T. (2005). Ecotypic variation in phosphorus acquisition mechanisms within marine picocyanobacteria. Aquatic Microbial Ecology 39, 257-269. 
Moutin, T., Thingstad, T.R., Van Wambeke, F., Marie, D., Slawyk, G., Raimbault, P. \& Claustre, H. (2002). Does competition for nanomolar phosphate supply explain the predominance of the cyanobacterium Synechococcus? Limnology \& Oceanography 47, 1562-1567.

Mózes, A., Présing, M. \& Vörös, L. (2006). Seasonal dynamics of picocyanobacteria and picoeukaryotes in a large shallow lake (Lake Balaton, Hungary). Internationale Reoue der gesamten Hydrobiologie 91, 38-50.

Muhling, M., Fuller, N.J., Millard, A., Somerfield, P.J., Marie, D., Wilson, W.H., Scanlan, D.J., Post, A.F., Joint, I. \& Mann, N.H. (2005). Genetic diversity of marine Synechococcus and cooccurring cyanophage community: evidence for viral control of phytoplankton. Environmental Microbiology 7, 499-508.

Muyzer, G., De Waal, E.C. \& Uitterlinden, A.G. (1993). Profiling of complex microbial populations by denaturing gradient gel electrophoresis analysis of polymerase chain reaction-amplified genes coding for $16 \mathrm{~S}$ rRNA. Applied Environmental Microbiology 59, 695-700.

Nagata, T., Takai, K., Kawanobe, K., Kim, D., Nakazato, R., Guselnikova, N., Bondarenko, N., Mologawaya, O., Kostrnova, T., Drucker, V., Satoh, Y. \& Watanabe, Y. (1994). Autotrophic picoplankton in southern Lake Baikal: abundance growth and grazing mortality during summer. Journal of Plankton Research 16, 945-959.

Nagata, T., Takay, K., Kawabata, K., Nakanishi, M. \& Urabe, J. (1996). The trophic transfer via a picoplankton-flagellatecopepod food chain during a picocyanobacterial bloom in Lake Biwa. Archiv für Hydrobiologie 137, 145-160.

Nedoma, J., Štrojsová, A., Vrba, J., Komárková, J. \& Šimek, K. (2003). Extracellular phospatase activity of natural plankton studied with ELF97 phosphate: fluorescence quantification and labelling kinetics. Environmental Microbiology 5, 462-472.

Not, F., Valentin, K., Romari, K., Lovejoy, C., Massana, R., Töbe, K., Vaulot, D. \& Medlin, L.K. (2007). Picobiliphytes: a marine picoplanktonic algal group with unknown affinities to other eukaryotes. Science 315, 253-255.

Olson, R.J., Vaulot, D. \& Chisholm, S.W. (1985). Marine phytoplankton distributions measured using shipboard flow citometry. Deep Sea Research 32, 1273-1280.

Padisák, J., Krienitz, L., Koschel, R. \& Nedoma, J. (1997). Deeplayer autotrophic picoplankton maximum in the oligotrophic
Lake Stechlin, Germany: origin, activity, development and erosion. European Journal of Phycology 32, 403-416.

Padisák, J., Krienitz, L., Scheffler, W., Kristiansen, J. \& Grigorszky, I. (1998). Phytoplankton succession in the oligotrophic Lake Stechlin, Germany. Hydrobiologia 370, 178-197.

Padisák, J., Scheffler, W., Kasprzak, P., Koschel, R. \& Krienitz, L. (2003a). Interannual changes (1994-2000) of phytoplankton of Lake Stechlin. Archiv für Hydrobiologie Special Issues Advances in Limnology 58, 101-133.

Padisák, J., Barbosa, F.A.R., Koschel, R. \& Krienitz, L. (2003b). Deep layer cyanoprokaryota maxima are constitutional features of lakes: examples from temperate and tropical regions. Archiv für Hydrobiologie Special Issues Advances in Limnology 58, 175-199. Passoni, S. \& Callieri, C. (2001). Picocyanobacteria single forms, aggregates and microcolonies: survival strategy or species succession? Verhandlungen der Internationale Vereinigung für theoretische und angewandte Limnologie 27, 1879-1883.

Passoni, S., Callieri, C. \& Heinimaa, S. (1997). Dinamiche di Distribuzione del Picoplancton Autotrofo nel Lago Maggiore. Atti $12^{\circ}$ Congresso AIOL Vol 1 (ed. M. Piccazzo), pp. 109-118.

Pernthaler, J., Šimek, K., Sattler, B., Schwarzenbacher, A., Bobkova, J. \& Psenner, R. (1996a). Short-term changes of protozoan control on autotrophic picoplankton in an oligo-mesotrophic lake. Journal of Plankton Research 18, 443-462.

Pernthaler, J., Sattler, B., Šimek, K., Schwarzenbacher, B. \& Psenner, R. (1996b). Top-down effects on the size-biomass distribution of a freshwater bacterioplankton community. Aquatic Microbial Ecology 10, 255-263.

Peštová, D., Macek, M. \& Martínez Pérez, M.E. (2007). Ciliates and their picophytoplankton-feeding activity in a high-altitude warm-monomictic saline lake. European Journal of Protistology, doi:10.1016/j.ejop.2007.04.004.

Pick, F.R. (1991). The abundance and composition of freshwater picocyanobacteria in relation to light penetration. Limnology $\mathcal{E}$ Oceanography 36, 1457-1462.

Pick, F.R. \& Agbeti, D.M. (1991). The seasonal dynamic and composition of photosynthetic picoplankton communities in temperate lakes in Ontario, Canada. Internationale Reoue der gesamten Hydrobiologie 76, 565-580.

Platt, T. \& Li, W.K.W. (1986). Photosynthetic picoplankton. Canadian Bulletin of Fisheries and Aquatic Sciences 214, 583 pp.

Ploug, H., Stolte, W. \& Jørgensen, B.B. (1999). Diffusive boundary 
layers of the colony-forming plankton alga Phaeocystis sp.implications for nutrient uptake and cellular growth. Limnology E Oceanography 44, 1959-1967.

Porter, K.G. (1975). Viable gut passage of gelatinous green algae ingested by Daphnia. Verhandlungen der Internationale Vereinigung für theoretische und angewandte Limnologie 19, 2840-2850.

Porter, K.G., Pearl, H., Hodson, R., Pace, M., Priscu, J., Riemann, B., Scavia, D. \& Stockner, J. (1988). Microbial interactions in lake food webs. In: Complex Interactions in Lake Communities (ed. S.R. Carpenter), pp. 209-228. Springer Verlag, New York.

Proctor, L.M. \& Fuhrman, J.A. (1990). Viral mortality of marine bacteria and cyanobacteria. Nature 343, 60-62.

Reche, I., Carrillo, P. \& Cruz-Pizarro, L. (1997). Influence of metazooplankton on interactions of bacteria and phytoplankton in an oligotrophic lake. Journal of Plankton Research 19, 631-646.

Reynolds, C.S., Huszar, V., Kruk, C., Naselli-Flores, L. \& Melo, S. (2002). Towards a functional classification of the freshwater phytoplankton. Journal of Plankton Research 24, 417-428.

Richards, T.A., Vepritskiy, A.A., Gouliamova, D.E. \& NierzwickiBauer, S.A. (2005). The molecular diversity of freshwater picoeukaryotes from an oligotrophic lake reveals diverse, distinctive and globally dispersed lineages. Environmental Microbiology 7, 1413-1425.

Rippka, R. (1988). Isolation and purification of cyanobacteria. In: Methods in Enzymology (eds L. Packer \& A.N. Glazer), vol. 167 Cyanobacteria, pp. 3-28. Academic Press, New York.

Robertson, B.R., Tezuka, N. \& Watanabe, M.M. (2001). Phylogenetic analyses of Synechococcus strains (Cyanobacteria) using sequences of $16 \mathrm{~S}$ rDNA and part of the phycocyanin operon reveal multiple evolutionary lines and reflect phycobilin content. International Journal of Systematic and Evolutionary Microbiology 51, 861-871.

Roff, J.C., Turner, J.T., Webber, M.K. \& Hopcroft, R.R. (1995). Bacterivory by tropical copepod nauplii: extent and possible significance. Aquatic Microbial Ecology 9, 165-175.

Ronneberger, D. (1998). Uptake of latex beads as size-model for food of planktonic rotifers. Hydrobiologia 387/388, 445-449.

Sanders, R.W., Porter, K.G., Bennet, S.J. \& DeBiase, A.E. (1989). Seasonal patterns of bacterivory by flagellates, ciliates, rotifers and cladocerans in a freshwater planktonic community. Limnology \& Oceanography 34, 673-687.

Scanlan, D.J. \& West, N.J. (2002). Molecular ecology of the marine cyanobacterial genera Prochlorococcus and Synechococcus. FEMS Microbiology Ecology 40, 1-12.

Schindler, D.W. (2006). Recent advantages in understanding and management of eutrophication. Limnology E Oceanography 51, 351-355.

Schütt, F. (1892). Analytische Planktonstudien. Lipsius \& Tischer.

Sicko-Goad, L. \& Stoermer, E.F. (1984). The need for uniform terminology concerning phytoplankton cell size fractions and examples of picoplankton from the Lauretian Great Lakes. Journal of Great Lakes Research 10, 90-93.

Sieburth, J.McN., Smetacek, V. \& Lenz, J. (1978). Pelagic ecosystem structure: heterotrophic compartments of the plankton and their relationship to plankton size fractions. Limnology $\mathcal{E}$ Oceanography 23, 1256-1263.

Šimek, K., Bobkova, J., Macek, M., Nedoma, J. \& Psenner, R. (1995). Ciliate grazing on picoplankton in a eutrophic reservoir during the summer phytoplankton maximum: a study at the species and community level. Limnology \& Oceanography 40, 1077-1090.

Šimek, K., Macek, M., Pernthaler, J., Straskrabová, V. \& Psenner, R. (1996). Can freshwater planktonic ciliates survive on a diet of picoplankton? Journal of Plankton Research 18, 597-613.

Simon, R.D. (1987). Inclusion bodies in the cyanobacteria: cyanophycin, polyphospate, polyhedral bodies. In: The Cyanobacteria (eds P. Fay \& C. Van Baalen), pp. 199-225. Elsevier, Amsterdam, New York.

Søndergaard, M. (1990). Picophytoplankton in Danish lakes. Verhandlungen der Internationale Vereinigung für theoretische und angewandte Limnologie 24, 609-612.

Staley, J.T. (1997). Biodiversity: are microbial species threatened? Current Opinion in Biotechnology 8, 340-345.

Stockner, J.G. (1991). Autotrophic picoplankton in freshwater ecosystems: the view from the summit. Internationale Revue der gesamten Hydrobiologie 76, 483-492.

Stockner, J.G. \& Antia, N.J. (1986). Algal picoplankton from marine and freshwater: a multidisciplinary perspective. Canadian Journal of Fisheries and Aquatic Sciences 43, 2472-2503.

Stockner, J.G. \& Porter, K.G. (1988). Microbial food webs in freshwater planktonic ecosystems. In: Complex Interactions in Lake Communities (ed. S.R. Carpenter), pp. 69-83. SpringerVerlag, Berlin.

Stockner, J.G. \& Shortreed, K.S. (1989). Algal picoplankton and contribution to food webs in oligotrophic British Columbia 
Lakes. Hydrobiologia 173, 151-166.

Stockner, J.G. \& Shortreed, K.S. (1991). Autotrophic picoplankton: community composition abundance and distribution across a gradient of oligotrophic British Columbia and Yukon Territory lakes. Internationale Revue der gesamten Hydrobiologie 76, 581-601.

Stockner, J., Callieri, C. \& Cronberg, G. (2000). Picoplankton and other non-bloom forming cyanobacteria in lakes. In: The Ecology of Cyanobacteria: their Diversity in Time and Space (eds B. Whitton \& M. Potts), pp. 195-238. Kluwer Academic Publishers, The Netherlands.

Stomp, M., Huisman, J., de Jongh, F., Veraart, A.J., Gerla, D., Rijkeboer, M., Ibelings, B.W., Wollenzien, U.I.A. \& Stal, L.J. (2004). Adaptive divergence in pigment composition promotesphytoplankton biodiversity. Nature 432, 104-107.

Stomp, M., Huisman, J., Vörös, L., Pick, F.R., Laamanen, M., Haverkamp, T. \& Stal, L.J. (2007). Colorful coexistence of red and green picocyanobacteria in lakes and seas. Ecology Letters 10, 290-298.

Straškrabová, V., Callieri, C. \& Fott, J. (eds) (1999). Pelagic food web in mountain lakes (Mountain Lakes Research Program). Journal of Limnology 58, 222 pp.

Štrojsová, A., Vrba, J., Nedoma, J., Komarková, J. \& Znachor, P. (2003). Seasonal study of extracellular phosphatase expression in the phytoplankton of a eutrophic reservoir. European Journal of Phycology 38, 295-306.

Sundt-Hansen, L.E., Olsen, Y., Stibor, H., Heldal, M. \& Vadstein, O. (2006). Trophic cascades mediated by copepods, not nutrient supply rate, determine the development of picocyanobacteria. Aquatic Microbial Ecology 45, 207-218.

Suttle, C. (2000). Cyanophages and their role in the ecology of cyanobacteria. In: The Ecology of Cyanobacteria: their Diversity in Time and Space (eds B. Whitton \& M. Potts), pp. 563-589. Kluwer Academic Publishers, The Netherlands.

Suttle, C.A. \& Chen, F. (1992). Mechanisms and decay rates of marine viruses in seawater. Applied and Environmental Microbiology 58, 3721-3729.

Takahashi, M \& Hori, T. (1984). Abundance of picophytoplankton in the subsurface chlorophyll maximum layer in subtropical and tropical waters. Marine Biology 79, 177-186.

Takano, H., Arai, T., Hirano, M. \& Matsunaga, T. (1995). Effects of intensity and quality of light on phycocyanin production by a marine cyanobacterium Synechococcus sp. NKBG 042902.
Applied Microbiology and Biotechnology 43, 1014-1018.

Tandeau de Marsac, N. (1977). Occurrence and chromatic adaptation in cyanobacteria. Journal of Bacteriology 130, 82-91.

Taylor, G.T. (1982). The role of pelagic heterotrophic protozoa in nutrient cycling: a review. Annales de l'Institute Ocèanographique 58, 227-241.

Timmermans, K.R., van der Wagt, B., Veldhuis, M.J.W., Maatman, A. \& de Baar, H.J.W. (2005). Physiological responses of three species of marine pico-phytoplankton to ammonium, phosphate, iron and light limitation. Journal of Sea Research 53, 109-120.

Urbach, E., Scanlan, D.J., Distel, D.L., Waterbury, J.B. \& Chisholm, S.W. (1998). Rapid diversification of marine picophytoplankton with dissimilar light-harvesting structure inferred from sequences of Prochlorococcus and Synechococcus (Cyanobacteria). Journal of Molecular Evolution 46, 188-201.

Vadstein, O. (2000). Heterotrophic planktonic bacteria and cycling of phosphorus: phosphorus requirements, competitive ability, and food web interactions. In: Advances in Microbial Ecology (ed. B. Schink), Vol. 16, pp. 115-167. Kluwer Academic Publisher, New York.

Van Donk, E. \& Hessen, D.O. (1993). Grazing resistance in nutrient-stressed phytoplankton. Oecologia 93, 508-511.

Van Mooy, B.A.S., Rocap, G., Fredericks, H.F., Evans, C.T. \& Devol, A.H. (2006). Sulfolipids dramatically decrease phosphorus demand by picocyanobacteria in oligotrophic marine environments. Proceedings of the National Academy of Science 103, 8607-8612.

Vaulot, D., Partensky F., Neveux, J., Mantoura, R.F.C. \& Llewellyn, C.A. (1990). Winter presence of prochlorophytes in surface waters of the North-Western Mediterranean Sea. Limnology $\mathcal{E}$ Oceanography 35, 1156-1164.

Veldhuis, M.J.W. \& Kraay, G.W. (1990). Vertical distribution of pigment composition of a picoplanktonic prochlorophyte in the subtropical north Atlantic: A combined study of pigments and flow cytometry. Marine Ecology Progress Series 68, 121-127.

Veldhuis, M.J.W. \& Kraay, G.W. (1993). Cell abundance and fluorescence of picoplankton in relation to growth irradiance and nitrogen availability in the Red Sea. Netherland Journal of Sea Research 31, 135-145.

Verduin, J. (1956). Energy fixation and utilization by natural communities in western Lake Erie. Ecology 37, 40-49. 
Vollenweider, R.A., Munavar, M. \& Stadelmann, P. (1974). A comparative review of phytoplankton and primary production in the Laurentian Great Lakes. Journal of Fisheries Research Board of Canada 31, 739-762.

Vörös, L., Gulyas, P. \& Nemeth, J. (1991). Occurrence, dynamics and production of picoplankton in Hungarian shallow lakes. Internationale Revue der gesamten Hydrobiologie 76, 617-629.

Vörös, L., Callieri, C., Balogh, K.V. \& Bertoni, R. (1998). Freshwater picocyanobacteria along a trophic gradient and light quality range. Hydrobiologia 369/370, 117-125.

Warden, A.Z. (2006). Picoeukaryote diversity in coastal waters of the Pacific Ocean. Aquatic Microbial Ecology 43, 165-175.

Waterbury, J.B. \& Valois, F.W. (1993). Resistance to co-occurring phages enables marine Synechococcus communities to coexist with cyanophages abundant in sea water. Applied Environmental Microbiology 59, 3393-3399.

Waterbury, J.B., Watson, S.W., Guillard, R.R.L. \& Brand, L.E.E. (1979). Widespread occurrence of a unicellular, marine, planktonic cyanobacterium. Nature 227, 293-294.

Wehr, J.D. (1993). Effects of experimental manipulation of light phosphorus supply on competition among picoplankton and nanoplankton in a oligotrophic lake. Canadian Journal of Fisheries and Aquatic Sciences 50, 936-945.

Weinbauer, M.G. (2004). Ecology of prokaryotic viruses. FEMS Microbiology Reviews 28, 127-181.

Weisse, T. (1990). Trophic interactions among heterotrophic microplankton, nanoplankton, and bacteria in Lake Constance (FRG). In: Relationships in Inland Waters. Hydrobiologia (eds P. Biró \& J.F. Talling) 191, 111-122.

Weisse, T. (1993). Dynamics of autotrophic picoplankton in marine and freshwater ecosystems. In: Advances in Microbial Ecology (ed. J.G. Jones), Vol. 13, pp. 327-370. Kluwer Academic Publisher, New York.

Weisse, T. \& Kenter, U. (1991). Ecological characteristics of autotrophic picoplankton in a prealpine lake. Internationale Revue der gesamten Hydrobiologie 76, 493-504.

Weisse, T. \& Schweizer, A. (1991). Seasonal and interannual variation of autotrophic picoplankton in a large prealpine lake (Lake Constance). Verhandlungen der Internationale Vereinigung für theoretische und angewandte Limnologie 24, 821-825.

Wyman, M. \& Fay, P. (1986). Underwater light climate and the growth and pigmentation of planktonic blue green algae
(Cyanobacteria). The influence of light quality. Proceedings of the Royal Society of London (B) 227, 381-393.

Wilmotte, A. \& Golubić, S. (1991). Morphological and genetic criteria in the taxonomy of Cyanophyta/Cyanobacteria. Archiv für Hydrobiologie, Algological Studies 64, 1-24.

Yoshida, T., Gurung, T.B., Kagami, M. \& Urabe, J. (2001). Contrasting effects of cladoceran (Daphnia galeata) and calanoid copepod (Eodiaptomus japonicus) on algal and microbial plankton in a Japanese lake, Lake Biwa. Oecologia 129, 602-610.

Zeidner, G., Bielawski, J.P., Shmoish, M., Scanlan, D.J., Sabehi, G. \& Beja, O. (2005). Potential photosynthesis gene recombination between Prochlorococcus and Synechococcus via viral intermediates. Environmental Microbiology 7, 1505-1513.

Zöllner, E., Santer, B., Boersma, M., Hoppe, H.G. \& Jürgens, K. (2003). Cascading predation effects of Daphnia and copepods on microbial food web components. Freshwater Biology 48, 2174-2193.

\section{Author Profile}

The author has worked in the 'Istituto Italiano di Idrobiologia', now Institute of Ecosystem Study -CNR, since the 1980s. In the first part of her scientific career, her interest was devoted to organic carbon and bacteria in the energy flux of aquatic food chains. She then became passionately fond of picocyanobacteria, discovering their importance in ultra- and oligotrophic lakes. She is still entrapped in the phylogenetic and ecophysiological study of picophytoplankton, allowing herself 'Pindaric flights' on mixotrophic grazers as interesting picoplankton grazers. 